\title{
Modulation of interactions of neuroblastoma cell lines with extracellular matrix proteins affects their sensitivity to treatment with the anti-GD2 ganglioside antibody 14G2a
}

\author{
IRENA HORWACIK and HANNA ROKITA \\ Laboratory of Molecular Genetics and Virology, Faculty of Biochemistry, \\ Biophysics and Biotechnology, Jagiellonian University, 30-387 Kraków, Poland
}

Received July 13, 2016; Accepted March 20, 2017

DOI: $10.3892 /$ ijo.2017.3959

\begin{abstract}
Children diagnosed with high risk neuroblastoma have poor prognosis which stimulates efforts to broaden therapies of the neoplasm. GD2-ganglioside (GD2) marks neuroblastoma cells and is a target for monoclonal antibodies. We have recently shown that some neuroblastoma cell lines are sensitive to direct cytotoxicity of the anti-GD2 mouse monoclonal antibody 14G2a (mAb). For IMR-32 and LA-N-1 cell lines, treatment with the $14 \mathrm{G} 2 \mathrm{a}$ mAb induced evident changes in appearance such as cell rounding, aggregation, loose contact with culture plastic, or detachment. Such findings prompted us to investigate whether modulation of attachment of neuroblastoma cells to extracellular matrix (ECM) proteins can affect their sensitivity to the $14 \mathrm{G} 2 \mathrm{a}$ mAb treatment. First, using ultra-low attachment plates, we show that survival of the IMR-32, LA-N-1, LA-N-5, CHP-134 and Kelly cells depends on attachment. Next, we compared cellular ATP levels of the cell lines treated with the 14G2a mAb using uncoated, fibronectin-, collagen IV-coated surfaces to show that the ECM proteins slightly modulate sensitivity of the cell lines to the mAb. Then, we characterized presence of selected integrin subunits or their complexes on the cell surface. Finally, we applied small molecule inhibitors of selected integrin complexes: obtustatin (inhibiting $\alpha 1 \beta 1$ heterodimer), BIO 1211 (inhibiting active $\alpha 4 \beta 1$ heterodimer), cilengitide and
\end{abstract}

Correspondence to: Dr Irena Horwacik, Laboratory of Molecular Genetics and Virology, Faculty of Biochemistry, Biophysics and Biotechnology, Jagiellonian University, Gronostajowa 7, 30-387 Kraków, Poland

E-mail: irena.horwacik@uj.edu.pl

Abbreviations: ECM, extracellular matrix; FBS, fetal bovine serum; FAK, focal adhesion kinase; GD2, GD2 ganglioside; GD3, GD3 ganglioside; mAb, monoclonal antibody; SB, SB273005; CGT, cilengitide; BSA, bovine serum albumin; VN, vitronectin; PBS, phosphate-buffered saline

Key words: neuroblastoma, GD2 ganglioside, 14G2a, integrin, obtustatin, cilengitide, SB273005, BIO 1211, extracellular matrix
SB273005 (inhibitors of $\alpha \mathrm{V} \beta 3, \alpha \mathrm{V} \beta 5$ heterodimers) to verify their effects on attachment of cell lines, cellular ATP levels, and in some experiments activities of apoptosis-executing caspase- 3 and -7 , for the compounds used alone or in combination with the $14 \mathrm{G} 2 \mathrm{a}$ mAb. We characterized levels of total FAK (focal adhesion kinase), p-FAK (Tyr397) in IMR-32 cells treated with BIO 1211, and in LA-N-5, Kelly and SK-N-SH cells treated with SB273005. Our results extend knowledge on factors influencing cytotoxicity of 14G2a.

\section{Introduction}

Neuroblastoma is a childhood malignancy arising from primitive neuroblasts of the sympathetic part of the peripheral nervous system. The disease is characterized by evident age dependence, which affects prevalence and prognosis (1). Hence, neuroblastoma is the most common type of tumor diagnosed in infancy, and the majority of cases are diagnosed in patients up to 5 years of age (after http://www.cancer.org/ cancer/neuroblastoma/detailedguide/neuroblastoma-keystatistics).

More importantly, children above 18 months of age have poor prognosis for overall survival (2). It should be stressed that heterogeneity is an intrinsic feature of neuroblastoma, despite limited landscape of genetic alterations (3). Thus, on the one hand, the disease may spontaneously regress in some patients, but on the other hand in about half of patients advanced aggressive tumors are diagnosed, which demand intensive multiagent and multimodal treatment (4). The fact that children with high risk neuroblastoma have poor prognosis fuels approaches to broaden treatment options for the group of patients.

GD2-ganglioside (GD2), a cell surface-exposed and sialic acid-containing glycosphingolipid, is a marker of neuroblastoma and a relevant target for anti-neuroblastoma immunotherapy with monoclonal antibodies (5). Since 2015, the treatment options for high risk patients that at least partially responded to first line therapy were widened with FDA-approval of a chimeric human mouse monoclonal antibody dinutuximab (ch14.18) (6). The antibody is used in line with 13-cis retinoic acid, IL-2 and GM-CSF to control minimal residual disease (7). Other GD2-specific antibodies such as mouse monoclonal antibodies 14G2a (sharing 
a paratope with ch14.18) or 3F8 either had been or are continuously being tested in clinics, respectively (5).

Several researchers have set goals to investigate mechanism of interactions of ganglioside-binding antibodies with cancer cells (reviewed in ref. 8). It is evident that, in addition to involvement of antibodies in immune-based mechanisms of cancer eradication, direct cytotoxic effects may result from binding of antibodies to tumor cells. Such data, including ours, are also available for anti-GD2 ganglioside antibodies and neuroblastoma $(9,10)$. Thus, we showed that some neuroblastoma cell lines are sensitive to direct cytotoxicity of the anti-GD2 antibody $14 \mathrm{G} 2 \mathrm{a}(\mathrm{mAb})$. Furthermore, we have already reported an increase in p53, but a drop of MYCN in nuclear protein fractions, a decrease in Aurora A kinase, and downregulation of activity of the Akt/mTOR signaling network, which correlated with decreased cellular ATP levels in IMR-32 neuroblastoma cells after the mAb treatment $(10,11)$. Also, we were able to show that 13-cis retinoic acid, Aurora A inhibitor MK-5108, a dual PI3K and mTOR inhibitor BEZ-235, when combined with 14G2a, can further decrease cellular ATP levels in some neuroblastoma cell lines $(10,11)$. The data add to efforts to screen for new drug combinations to improve survival of cancer patients.

Integrins are a group of transmembrane proteins connecting cells to extracellular matrix of intercellular spaces and basement membranes, via binding to proteins such as fibronectin, collagens, laminin and vitronectin. The receptors are responsible for signal transduction regulated from cell outside, after ligand-induced activation of integrin complexes, and from cell inside, due to activity of specific protein complexes associating with cytoplasmic domains of integrins $(12,13)$. In mammals, 24 heterodimeric complexes, differing in their ligand selectivity, can be formed utilizing one of $18 \alpha$ and one of $8 \beta$ subunits (12). In cancer cells, roles of specific integrin subunits or complexes in regulation of migration, survival, angiogenesis and metastasis are intensively studied (14). Characterization of biological roles of integrins fuelled development and clinical trials of their antagonists, in the form of antibodies such as etaracizumab (15), volociximab (16), and inhibitors, e.g., cilengitide (17). Some links between neuroblastoma phenotype and integrins have also been established. Thus, in 2015 Young et al (18) showed that integrin $\alpha 4$ may be correlated with poor outcome of neuroblastoma patients diagnosed with tumors without $M Y C N$ amplification and possibly allows for their further classification. Also, Lee et al (19) showed that overexpression of gastrin-releasing peptide in neuroblastoma increases expression of integrins $\alpha 2, \alpha 3, \beta 1$ and used siRNA to show that integrin $\beta 1$ was necessary for SK-N-SH migration. Additionally, links between tumor cell attachment, integrins and gangliosides are one of the areas of research. Cheresh et al (20) reported that M21 human melanoma cells are detached from fibronectin-coated wells by the anti-GD3 ganglioside (GD3) MB3.6 mAb. Ohkawa et al (21) found that GD3-positive melanoma cells exhibited stronger adhesion to collagen I and collagen IV, as compared to GD3-negative counterparts. They also showed that $\beta 1$ integrin and GD3 co-localized at points of focal adhesion.

One of the features often observed in cells cultures treated with ganglioside binding antibodies are changes in their morphology, i.e., more rounded appearance, aggregation, loose surface adherence, or detachment. Thus, Dippold et al (22) reported such changes in a panel of melanoma cell lines treated with the anti-GD3 mouse R-24 mAb. Cochonneau et al (9) showed morphology changes of IMR-5 cells treated with the anti- $O$-acetyl GD2 8B6 and the anti-GD2 10B8 mAbs. We noted such features in IMR-32 and LA-N-1 neuroblastoma cell cultured with the anti-GD2 14G2a mAb (10,23). Also, we showed that $14 \mathrm{G} 2 \mathrm{a}$ in a dose-dependent manner interferes with attachment of IMR-32 cells to fibronectin (23). Therefore, we applied selective inhibitors of integrin complexes $\alpha 1 \beta 1$ (obtustatin) (24), $\alpha 4 \beta 1$ (BIO 1211) (25) and $\alpha \mathrm{V} \beta 3 / \alpha \mathrm{V} \beta 5$ [cilengitide (26), SB273005 (27)] to seek answers whether inhibition of integrin binding to extracellular matrix proteins affects sensitivity of neuroblastoma cells to treatment with the antiGD2 14G2a mAb.

Based on our previous results, we used five GD2-positive neuroblastoma cell lines with varying sensitivity to the 14G2a mAb (10), i.e., IMR-32, LA-N-1, LA-N-5, CHP-134, Kelly and GD2-negative SK-N-SH cells to characterize expression of some integrin subunits and complexes. Also, we measured effects of the aforementioned inhibitors on cell attachment and survival. Finally, as our goal was to broaden knowledge on factors affecting cytotoxicity of the $14 \mathrm{G} 2 \mathrm{a}$ mAb against neuroblastoma cell lines, we report effects of the inhibitors and the 14G2a mAb, used as single agents or combined, on attachment and cell survival.

\section{Materials and methods}

Cell culture of neuroblastoma cell lines. In our experiments, we used six human neuroblastoma cell lines obtained from cell collections, i.e., IMR-32 (ATTC, LCG Standards, Lomianki, Poland; cat no. CCL-127), LA-N-1 (ECACC, Sigma-Aldrich, Poznan, Poland; cat. no. 06041201), CHP-134 (ECACC, cat. no. 06122002), LA-N-5 (cat. no. ACC 673; Leibniz-Institut DSMZDeutsche Sammlung von Mikroorganismen und Zellkulturen GmbH), Kelly (cat. no. ACC 355; DSMZ) and SK-N-SH (cat. no. ATCC HTB11). Cells were cultured in $5 \% \mathrm{CO}_{2}$ atmosphere in media as previously described in detail (10).

Anti-GD2 ganglioside antibody purification. The hybridoma cell line producing the $14 \mathrm{G} 2 \mathrm{a}$ mAb, which is a mouse $\operatorname{IgG} 2 \mathrm{a}$ that binds to GD2, was kindly provided by Dr R.A. Reisfeld (Scripps Research Institute, La Jolla, CA, USA). Cell culture and the antibody purification from fetal bovine serum (FBS) free-cell culture supernatant using HiTrap ${ }^{\mathrm{TM}}$ Protein G columns (cat. no. 17-0404-03; GE Healthcare Bio-Sciences AB, Uppsala, Sweden) were previously described in detail (10).

Detection of integrins expressed on neuroblastoma cell lines with a cell adhesion array. Analyses of integrin content of cells were performed with Alpha/Beta Integrin-Mediated Cell Adhesion Array Combo kit (cat. no. ECM532; Chemicon International, Merck Sp.zo.o., Warszawa, Poland) with protocol optimized based on the manufacturer's suggestions. Prior to the tests, neuroblastoma cells were detached from culture plastic vessels with $2 \mathrm{mM}$ EDTA in phosphate-buffered saline (PBS, cat. no. PBS404.2; BioShop ${ }^{\circledR}$ Canada, Lab Empire, Rzeszów, Poland), at room temperature and then centrifuged (for $10 \mathrm{~min}$, at $4^{\circ} \mathrm{C}$, at $315 \mathrm{x} \mathrm{g}$ ). The cell pellets were resuspended in assay 
Table I. Flow cytometric analysis of GD2 expression on neuroblastoma cell lines. ${ }^{\mathrm{a}}$

\begin{tabular}{lcc}
\hline Cell line & $\begin{array}{c}\text { Percentage of } \\
\text { positive staining (\%) }\end{array}$ & $\begin{array}{c}\text { Median fluorescence } \\
\text { intensity (MFI) }\end{array}$ \\
\hline IMR-32 & 95.1 & 37018 \\
CHP-134 & 98.6 & 31427 \\
LA-N-5 & 97.1 & 40311 \\
Kelly & 93.8 & 37872 \\
SK-N-SH & 1 & $-^{-}$ \\
\hline
\end{tabular}

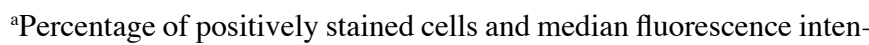
sity (MFI) of analyzed populations stained with the anti-GD2 14G2a $\mathrm{mAb}$ antibodies were derived from histogram plots (Materials and methods for details). Control samples of each cell line were stained with the PK136 mAb (an isotype control) and used to gate pools of the positively stained cells. Percentage of positive cells was set at $\sim 1 \%$ for cells stained with PK136. Data from one experiment is shown. ${ }^{b}$ No MFI is reported for SK-N-SH, as there was no difference in percent of positive staining for the two antibodies used.

buffer provided by the kit manufacturer and cells were counted using the trypan blue exclusion method. Between $0.1 \times 10^{6}$ and $0.2 \times 10^{6}$ of cells in $100 \mu \mathrm{l}$ of assay buffer (depending on the cell line tested) were added per well, followed by incubation for $2 \mathrm{~h}$ at $37^{\circ} \mathrm{C}$ in an incubator with $5 \%$ of $\mathrm{CO}_{2}$. Single wells with antibodies binding respective integrin subunits or complexes (also single negative control wells, NC) were used per experiment. Then, the cells were processed according to the manufacturer's instructions. Signals of absorbance at $560 \mathrm{~nm}$ were collected with an Infinite M200 reader (Tecan Schweiz AG, Männedorf, Switzerland). To normalize signals between experiments, we calculated ratios between signals from wells coated with, respective, anti-integrin antibodies and signals of negative control wells (NC). Two experiments are shown for IMR-32, CHP-134, LA-N-5, Kelly (marked as ex-1, ex-2 in Fig. 4). One experiment was performed for $\mathrm{LA}-\mathrm{N}-1$ cells.

Flow cytometry. Cells were detached using $2 \mathrm{mM}$ EDTA in PBS at room temperature, and 2\% FBS in PBS (FBS, cat. no. 10270-106; Life Technologies, Warszawa, Poland) was used for cell staining and washing. Following antibodies were applied: the 14G2a mAb for GD2 staining, while PK136 mAb (mouse IgG2a) (10) was used as an isotype control; FITC-conjugated anti-CD49d (integrin $\alpha 4$ ) antibody (IgG1, cat. no. 304315; BioLegend, BioCourse.pl, Katowice, Poland), while FITCconjugated mouse IgG1 mAb (cat. no. 400109; BioLegend) was used as an isotype control; mouse anti-human CD29 (integrin $\beta 1$ ) mAb (IgG1, cat. no. 303001; BioLegend), mouse anti-human integrin $\alpha \mathrm{V} \beta 3 \mathrm{mAb}$ (IgG1, cat. no. MAB1976Z; EMD Millipore Corp.), mouse anti-human integrin $\alpha \mathrm{V} \beta 5$ mAb (IgG1, cat. no. MAB1961Z; EMD Millipore), while purified mouse IgG1 was used as an isotype control (cat. no. 554721; BD Biosciences, Diag Med, Warszawa, Poland). Were appropriate, mouse Ig-specific FITC-conjugated goat $\mathrm{F}\left(\mathrm{ab}^{\prime}\right)_{2}$ fragments (cat. no. 55526; Cappel, MP Biomedicals, LLC, Warszawa, Poland) were used to detect binding of the primary antibodies. Cells were analyzed using flow cytometer
Table II. Flow cytometric analysis of selected integrin expression on neuroblastoma cell lines. ${ }^{\mathrm{a}}$

\begin{tabular}{lrrrr}
\hline & $\alpha 4(\%)$ & $\beta 1(\%)$ & $\alpha \mathrm{V} \beta 3(\%)$ & $\alpha \mathrm{V} \beta 5(\%)$ \\
\hline IMR-32 & $31.1 \pm 7.3$ & $68.0 \pm 0.5$ & $0.3 \pm 0.2$ & $0.2 \pm 0.1$ \\
CHP-134 & $2.8 \pm 0.6$ & $96.4 \pm 0.1$ & $2.2 \pm 0.5$ & $2.1 \pm 0.5$ \\
LA-N-5 & $1.2 \pm 0.4$ & $71.1 \pm 8.5$ & $1.8 \pm 0.0$ & $3.0 \pm 0.4$ \\
Kelly & $6.5 \pm 0.5$ & $84.7 \pm 3.3$ & $2.2 \pm 0.2$ & $62.2 \pm 6.5$ \\
SK-N-SH & $70.1 \pm 6.4$ & $99.6 \pm 0.3$ & $88.5 \pm 5.2$ & $86.4 \pm 10.4$ \\
\hline
\end{tabular}

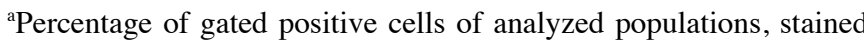
with antibodies specific to selected integrins, is shown. For all control samples, stained with specificity control antibodies, percentage of gated positive cells was set as $1 \%$. Data are shown as the means of two experiments $( \pm \mathrm{SEM})$.

BD $^{\mathrm{TM}}$ LSR II with BD FACSDiva software (BD Biosciences, Warszawa, Poland). Single cells were analyzed. Dead cells were excluded with 7-AAD viability staining solution (cat. no. 420403; BioLegend). For GD2 analyses, histograms showing levels of FITC fluorescence were analyzed. Pools of the positively stained cells were gated based on the signals from control cell samples, in which the PK136 mAb was used instead of the 14G2a mAb for staining (Table I). For measurements of integrin expression, scatter plots (showing levels of 7-AAD fluorescence vs. levels of FITC fluorescence) were analyzed. Gates to measure percentage of positively stained cells of the analyzed pools were set based on signals from cells stained with respective isotype control antibodies (Table II).

Plates used in experiments. We used several types of 96- or 6-well plates for cell culture. The plates include: a standard cell culture plate (cat. no. 353072; BD Falcon, Immunogen Polska, Chorzów, Poland), white/clear tissue culture treated plates (cat. no. 353377; BD Falcon, Immunogen Polska), human vitronectin coated plates (BSA, bovine serum albumin-blocked by the manufacturer, with only BSA-blocked wells included on the same plate, cat. no. CWP003; R\&D Systems, Biokom Sp.j, Janki, Poland), Nunclon ${ }^{\mathrm{TM}}$ Sphera $^{\mathrm{TM}}$ flat bottom cellware (cat. no. 174927; Thermo Fisher Scientific, Biokom), collagen type IV plates (cat. no. 354429; BD BioCoat ${ }^{\mathrm{TM}}$, Immunogen Polska); and human fibronectin cellware (cat. no. 354409; Corning BioCoat $^{\mathrm{TM}}$, Immunogen Polska, cat. no. 354402; Corning BioCoat $^{\mathrm{TM}}$, Diag Med). For some attachment assays and for western blots, cells were grown on wells coated with human vitronectin (cat. no. G5381; Promega Gmbh, Mannheim, Germany) and blocked with BSA (cat. no. A9418; SigmaAldrich) based on the manufacturer's protocol.

Scrambled and GD2-mimicking peptides, integrin inhibitors. \#94-12-F/W-AAEGD peptide [GD2 MIMIC (RCNPNMEPPRCWAAEGD) $(28,29)]$ and the scrambled peptide [SCR CONTROL (NPERCNRWMPCPAEADG)] were obtained from GenScript Biotech Corp. (Piscataway, NY, USA; dissolved in water). We used four integrin inhibitors: obtustatin, an inhibitor of $\alpha 1 \beta 1$ (dissolved in water, cat. no. 4664; Tocris Bioscience, Biokom); BIO 1211, an inhibitor 
of active $\alpha 4 \beta 1$ (dissolved in 20X PBS, cat. no. 3910, Tocris Bioscience, Biokom); cilengitide, an inhibitor of $\alpha \mathrm{V} \beta 3$ and $\alpha \mathrm{V} \beta 5$ (dissolved in DMSO, cat. no. S7077; Selleck Chemicals LLC, STI, Poznań, Poland); and SB273005, an inhibitor of $\alpha \mathrm{V} \beta 3$ and $\alpha \mathrm{V} \beta 5$ (dissolved in DMSO, cat. no. S7540; Selleck Chemicals LLC, STI).

Treatment of cells with the 14G2a mAb, the peptides and the inhibitors of integrins. Prior to the tests, neuroblastoma cells were detached from culture plastic with $2 \mathrm{mM}$ EDTA in PBS, at room temperature, and then centrifuged (for $10 \mathrm{~min}$, at $4^{\circ} \mathrm{C}$, at $139 \mathrm{x} \mathrm{g}$ ). The cell pellets were resuspended in respective complete media and counted using the trypan blue exclusion method. The seeding density for IMR-32 and LA-N-1 was $2 \times 10^{4}$ cells/100 $\mu \mathrm{l} /$ well and for CHP-134, LA-N-5, Kelly, SK-N-SH was $5 \times 10^{3}$ cells $/ 100 \mu \mathrm{l} /$ well. For $14 \mathrm{G} 2 \mathrm{a}$-treatment of cells, the antibodies in PBS were added (control samples were treated with PBS alone when necessary). All samples with cells were incubated on ice for $1 \mathrm{~h}$ with mixing after every $15 \mathrm{~min}$ of incubation, before transfer of $100 \mu \mathrm{l}$ to wells of respective plates.

Where appropriate, inhibitors (see above) were added to cells, after incubation with the 14G2a mAb (controls treated with solvents of inhibitors were included where necessary). Obtustatin was tested at the concentrations of $0.012,0.06,0.3$ and $1.5 \mu \mathrm{M}$; BIO 1211 was tested at the concentrations of $1,2.5$ and $5 \mu \mathrm{M}$; cilengitide was tested at the concentrations of 3 and $10 \mu \mathrm{M}$; and SB273005 was tested at the concentrations $0.3,1$, 3,10 and $30 \mu \mathrm{M}$.

For testing of effects of \#94-12-F/W-AAEGD or scrambled control peptides on cytotoxicity of the $14 \mathrm{G} 2 \mathrm{a}$ mAb, the seeding density for IMR-32 and CHP-134 cell lines was $2 \times 10^{4}$ cells/100 $\mu \mathrm{l} /$ well to better fit microscopic examinations. The peptides were added to cells after incubation with antibodies on ice (from $10 \mathrm{mM}$ stock solution) to the final concentrations of 0.23 or $0.114 \mathrm{mM}$. Separate controls cells (when necessary) were also treated with peptides, and/or diluent of peptides, and/or PBS (diluent for 14G2a) to check for any effects on cellular ATP levels.

After the above treatments, cells were incubated for $72 \mathrm{~h}$ at $37^{\circ} \mathrm{C}$ in an incubator with $5 \%$ of $\mathrm{CO}_{2}$. On the third day of incubation microscopic pictures were taken of some cell cultures using the Leica microscope DM IL LED Fluo equipped with the DFC450C camera, using 10x- (506263, HI PLAN I, 10x/0.22) or x 20-magnification objectives (506264, HI PLAN I, 20x/0.30) and collected using the Leica Application Suite Version 4.3.0 (Leica Microsystems GMBH, Wetzlar, Germany). Cellular survival (based on measurements of ATP levels) or caspase-3/-7 activities were determined as described below.

For attachment assays, the seeding density for all cell lines was $2 \times 10^{4}$ cells $/ 100 \mu \mathrm{l} /$ well. Cells were treated with integrin inhibitors, $14 \mathrm{G} 2 \mathrm{a}$, or their combinations (see above), and then incubated for $2 \mathrm{~h}$ at $37^{\circ} \mathrm{C}$ in an incubator with $5 \%$ of $\mathrm{CO}_{2}$. Control cells treated with diluents were included (were necessary). Next, unattached cells were removed by inversion of plates, while the remaining cells were analyzed using cellular ATP measurements (see below). For western blot analysis, LA-N-5, Kelly and SK-N-SH cells were treated with $3 \mu \mathrm{M}$ SB273005 for 6 and 24 h, IMR-32 cells were treated with
$5 \mu \mathrm{M}$ BIO 1211 for 6 and $24 \mathrm{~h}$. Control cells were treated with diluents.

Measurements of viable cell number through determination of levels of ATP and analysis of apoptosis through determination of caspase-3/-7 activities in cell cultures. We used an ATP assay as a sensitive method to estimate viable cell number in attachment experiments, and to determine effects of tested agents (the 14G2a mAb, the peptides and the integrin inhibitors) on neuroblastoma cell viability (proliferation and cytotoxicity). Cellular ATP contents were analyzed using ATPlite, luminescence ATP detection assay system (cat. no. 6016947; Perkin-Elmer, Warszawa, Poland) based on the protocol of the manufacturer to measure cell survival in experiments. For measurements of activities of apoptosis-executing caspase-3/-7, we used Caspase-Glo ${ }^{\circledR}$ 3/7 assay (cat. no. G8091; Promega) according to the manufacturer's protocol. Where necessary, equal volumes of cell lysates were transferred to white plates and luminescence signals were collected using the Infinite M200 reader.

Western blot analysis. Cells were collected using trypsinEDTA (cat. no. T3924; Sigma-Aldrich) and centrifuged for $5 \mathrm{~min}\left(2,500 \mathrm{x} \mathrm{g}\right.$ at $\left.4^{\circ} \mathrm{C}\right)$. Cell pellets were washed twice with ice-cold PBS (with centrifugation steps to recover cells as pellet). Next, cells were lysed with gentle mixing by inversion (for $45 \mathrm{~min}$, at $4^{\circ} \mathrm{C}$ ) using buffer containing: $25 \mathrm{mM}$ Tris- $\mathrm{HCl}$ (pH 7.6, cat. no. TRS001.1; BioShop), $10 \mathrm{mM} \mathrm{NaCl}$ (cat. no. 794121116; Avantor Performance Materials Poland S.A., POCH, Gliwice, Poland), 1\% NP-40 (cat. no. NON999.500; BioShop), $1 \%$ sodium deoxycholate (cat. no. D6570; SigmaAldrich), 0.1\% SDS (cat. no. L4390; Sigma-Aldrich), Halt Phosphatase Inhibitor Cocktail (cat. no. 78420; Thermo Fisher Scientific, ALAB Laboratoria, Warszawa, Poland), and Complete Protease Inhibitor Cocktail (cat. no. 11697498001; Roche, Warszawa, Poland). Then, samples were centrifuged $14,000 \times \mathrm{g}$, at $4^{\circ} \mathrm{C}$, for $15 \mathrm{~min}$. Samples were resolved using SDS-PAGE (12\% gels) as described in detail (10). Western blot analyses were performed with application of the following antibodies (all from Cell Signaling Technology-Lab-JOT Ltd., Warszawa, Poland): anti-FAK (cat. no. 13009, dilution 1:1,00), anti-phospho-FAK (Tyr397) (cat. no. 8556, dilution 1:1,000), anti- $\alpha$-tubulin (cat. no. 2125, dilution 1,000-2,000), anti-rabbit IgG, HRP-linked antibody (cat. no. 7074, 1:2,000). Chemiluminescent signals were developed with the Immobilon Western HRP Substrate (cat. no. WBKLS0500; Millipore, Warszawa, Poland) and collected using the MicroChemi System (DNR Bio Imaging Systems, ALAB Laboratoria, Warszawa, Poland).

Statistical analyses. Multivariate analysis was performed with one-way repeated measures ANOVA with a GreenhouseGeisser correction. Then, we performed post hoc pairwise comparisons by Dunnett's test at the significance levels set at $0.05,0.01,0.001$ were applicable. In multivariate analyses data were analyzed without normalization (30). Data shown on graphs were normalized to control set as 1 for clarity. Data on graphs (except for Fig. 4) are presented as means of experiments (n, numbers of experiments performed were from 2 to 5 , performed in duplicate, triplicate or quadruplicate, 
A
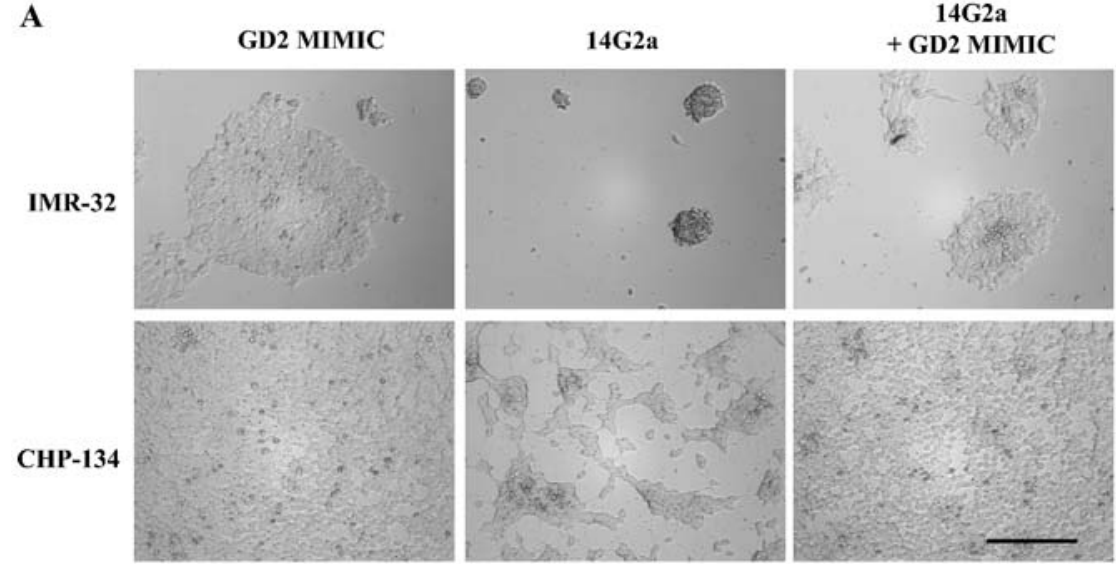

B

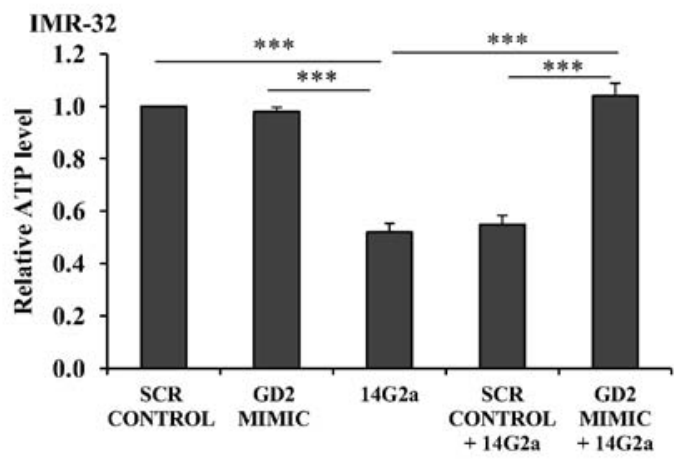

C

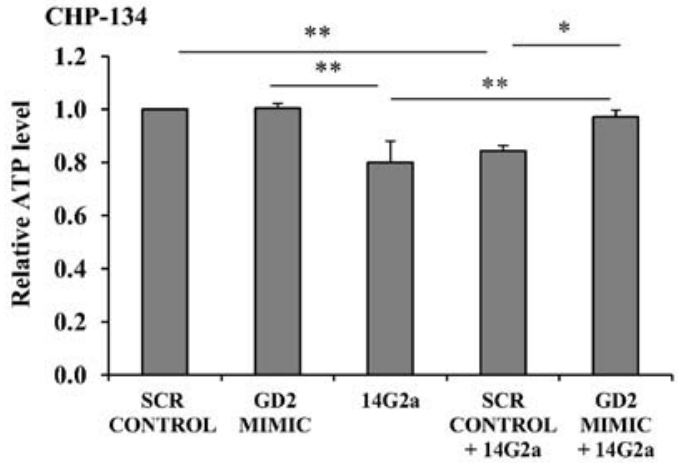

Figure 1. The peptide mimicking GD2-ganglioside blocks cytotoxic effects of the 14G2a mAb. (A) Representative microscopic pictures of IMR-32 and CHP134 cells treated with the $0.23 \mathrm{mM}$ concentration of the GD2-mimcking peptide (RCNPNMEPPRCWAAEGD, marked as GD2 MIMIC on the figure) and PBS (left panel); the 14G2a mAb (20 $\mu \mathrm{g} / \mathrm{ml}$, middle panel) and peptide diluent; and the GD2 MIMIC and the 14G2a mAb (right panel). The magnification objective x20 was used, scale bar, $250 \mu \mathrm{m}$. ATP levels in (B) IMR-32 and (C) CHP-134 cells were measured $72 \mathrm{~h}$ after the treatment with the scramble control peptide (SCR CONTROL, $0.23 \mathrm{mM}$ ) and PBS; GD2 MIMIC (0.23 mM) and PBS; 14G2a $(20 \mu \mathrm{g} / \mathrm{ml})$ and peptide diluent; and each peptide and the 14G2a mAb. ATP levels were calculated relative to values of cells treated with SCR CONTROL (set as 1 in the figures). Data were calculated as means of three experiments, run in triplicate, with SEM on the error bars. Multivariate analysis was performed with one-way repeated measures ANOVA with a Greenhouse-Geisser correction $[(\mathrm{B})-\mathrm{F}(1.397,2.795)=54.178, \mathrm{P}<0.0062$, (C) $-\mathrm{F}(1.516,3.031)=12.062, \mathrm{P}=0.0374]$. Pairwise comparisons by Dunnett's test at the significance levels " $\mathrm{P}<0.05$, ${ }^{* *} \mathrm{P}<0.01$ and ${ }^{* * *} \mathrm{P}<0.001$ vs. SCR CONTROL, vs. 14G2a, vs. SCR PEPTIDE + 14G2a. (B) The means of SCR CONTROL or GD2 MIMIC vs. SCR CONTROL $+14 \mathrm{G} 2 \mathrm{a}$ were statistically different at the level set at 0.001 (omitted from the graph for clarity). (C) The means of SCR CONTROL vs. 14G2a, and GD2 MIMIC vs. SCR CONTROL + 14G2a were statistically different at the level set at 0.01 (omitted from the graph for clarity).

as described in the figure legends) \pm SEM (a standard error of the mean). Data in Table II are presented as means of two experiments \pm SEM. Some normalized samples were analyzed using two-sample t-tests, comparing, e.g., values of control cells with values of treated cells to measure statistical significance [p-values: $\mathrm{P}<0.05, \mathrm{P}<0.01, \mathrm{P}<0.001]$. Statistical analyses were performed with the OriginPro 2017 (b9.4.0.220; OriginLab Corp., Northampton, MA, USA; one-way repeated measures ANOVA) and Microsoft Excell (Microsoft Corp., Way Redmond, WA, USA; t-tests). Microsoft software was used for the preparation of the graphs.

\section{Results}

A peptide mimicking GD2 ganglioside blocks cytotoxic effects of $14 G 2 a \mathrm{mAb}$. Phage-displayed peptide libraries can be screened with monoclonal antibodies with various specificities and yield mimicking peptides binding to the screening molecules and inhibiting interactions with the cognate antigens. Previously, we reported optimization and characterization of binding to the $14 \mathrm{G} 2 \mathrm{a}$ mAb of cyclic peptides mimicking GD2 ganglioside $(28,29)$. In the present study, we show that peptide \#94-12F/W-AAEGD (RCNPNMEPPRCWAAEGD, 


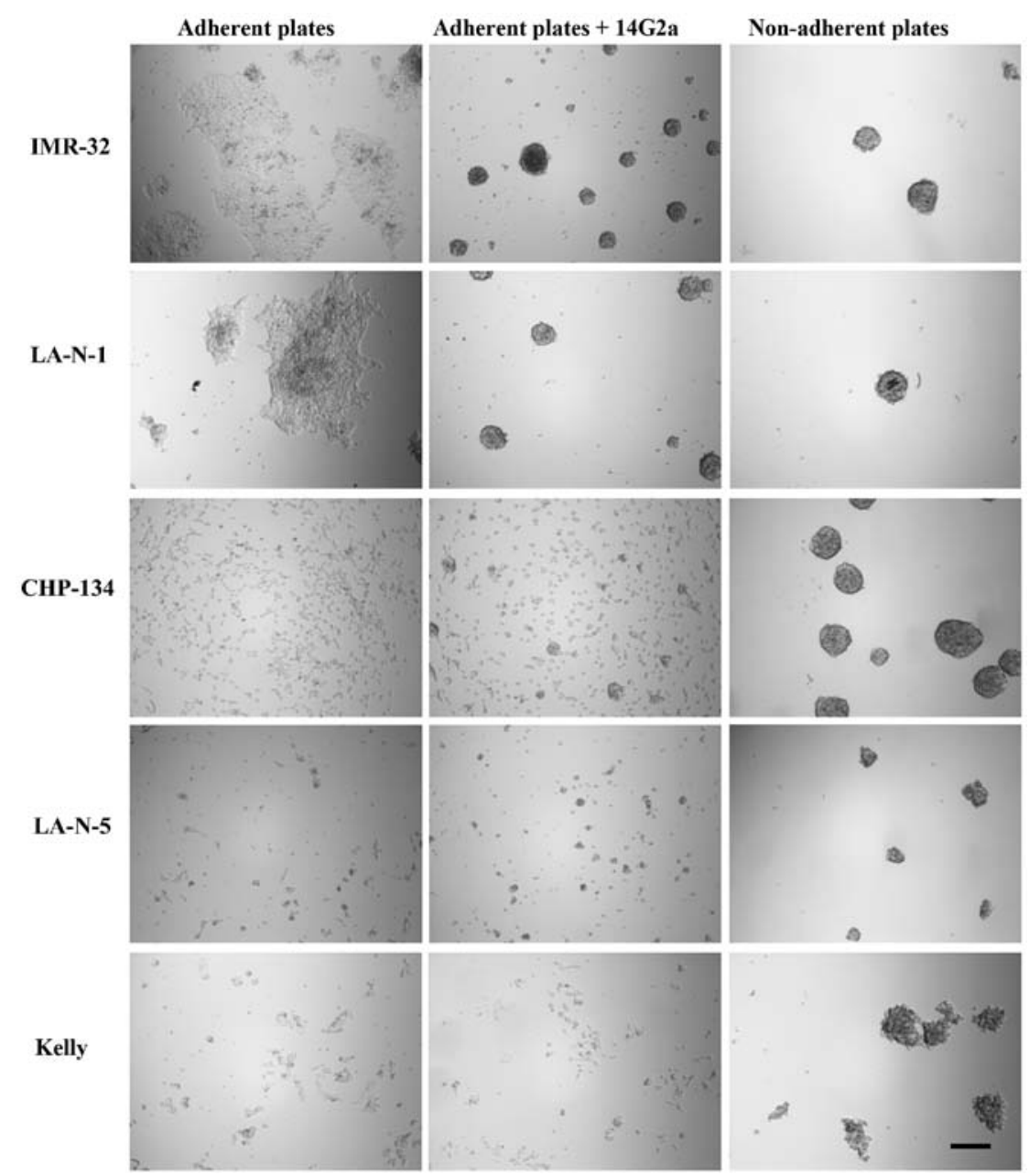

Figure 2. Survival of neuroblastoma cells is dependent on attachment. Representative microscopic pictures of IMR-32, LA-N-1, CHP-134, LA-N-5 and Kelly cells cultured for three days on adherent plates (left panel), adherent plates in the presence of the $14 \mathrm{G} 2 \mathrm{a} \mathrm{mAb}(20 \mu \mathrm{g} / \mathrm{ml}$, central panel), and non-adherent plates (right panel). The magnification objective 10x was used, scale bar, $250 \mu \mathrm{m}$.

marked as GD2 MIMIC in Fig. 1), used at the concentration $0.23 \mathrm{mM}$ (also $0.114 \mathrm{mM}$ concentration; data not shown), can abolish the cytotoxic effects of the $14 \mathrm{G} 2 \mathrm{a} \mathrm{mAb}$ as compared to the control scrambled sequence (marked as SCR PEPTIDE, NPERCNRWMPCPAEADG). IMR-32 and CHP-134 cells grown in the presence of the $14 \mathrm{G} 2 \mathrm{a} \mathrm{mAb}$ exhibited morphological changes such as cell aggregation. The effects were abolished by the GD2 MIMIC (Fig. 1A, images taken $72 \mathrm{~h}$ after incubation). Also, for both cell lines, the ATP levels in the presence of the GD2 MIMIC and the $14 \mathrm{G} 2 \mathrm{a}$ mAb were statistically significantly higher than in cells treated with the SCR PEPTIDE and the mAb (Fig. 1B; GD2 MIMIC + 14G2a vs. SCR PEPTIDE + 14G2a by Dunnett's test with the significance level set at 0.001; and Fig. 1C, GD2 MIMIC + 14G2a vs. SCR PEPTIDE + 14G2a by Dunnett's test with the significance level set at 0.05). There was no statistically significant difference between ATP cell levels in samples treated with $14 \mathrm{G} 2 \mathrm{a}$ or $14 \mathrm{G} 2 \mathrm{a}$ and SCR peptide (Dunnett's test), thus, the scrambled control peptide did not affect sensitivity of cells to the mAb. Moreover, there was no statistically significant difference between cells treated with SCR PEPTIDE and GD2 MIMIC (Dunnett's test). Therefore, the fact that the GD2 mimicking peptide, but not the control sequence, eliminated the cytotoxic effects of 14G2a confirms that the observed effects rely on binding of the mAb to GD2 ganglioside. In our previous study, we used the PK136 mAb as a negative control (10). Hence, the data obtained with the peptide provide additional evidence that the cytotoxic effects of $14 \mathrm{G} 2 \mathrm{a}$ are specific and require binding between GD2 and 14G2a.

Survival of the neuroblastoma cell lines is dependent on attachment. We have previously published data showing that selected neuroblastoma cell lines are sensitive to direct cytotoxicity of the anti-GD2 antibody 14G2a mAb (10,23). Thus, we measured that cellular ATP levels decreased in time- and dose-dependent manner in cultures of some neuroblastoma cells treated with the mAb (10). Additionally, for IMR-32 and LA-N-1 cell lines treatment with the mAb induced clear changes in appearance such as cell rounding, aggregation, detachment (10) (Fig. 2). For other cells, such as LA-N-5 and CHP-134 the changes were less pronounced (10) (Fig. 2). Kelly cells did not exhibit easily visible changes in their morphology and were only to a limited extent sensitive to the mAb treatment (10) (Fig. 2).

The above findings prompted us to hypothesize that modulation of attachment of cells may influence sensitivity of neuroblastoma cell lines to 14G2a. Hence, we used IMR-32, 
A

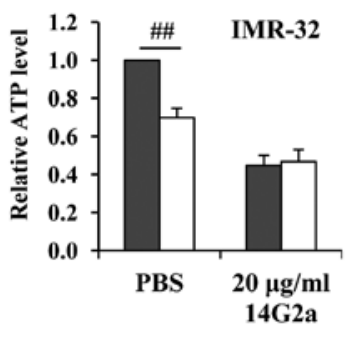

D

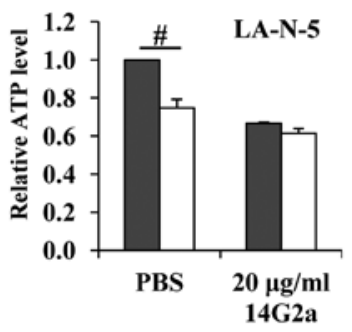

F

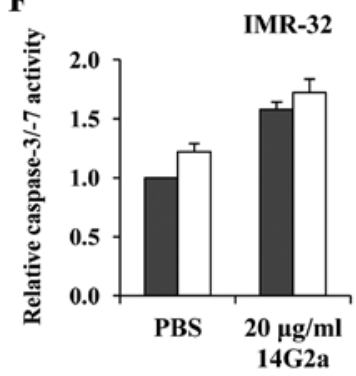

I

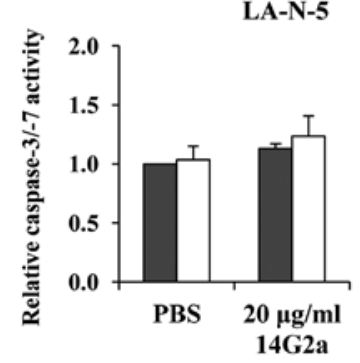

B

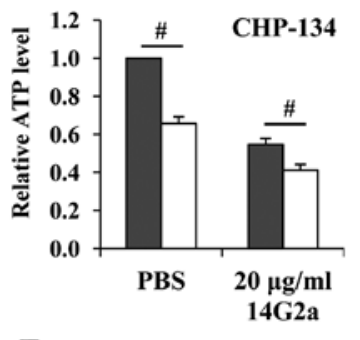

E

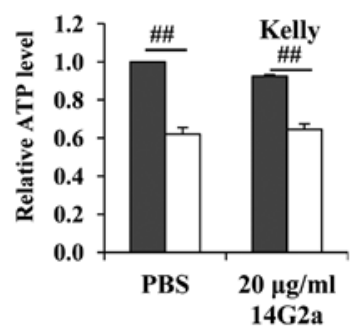

G
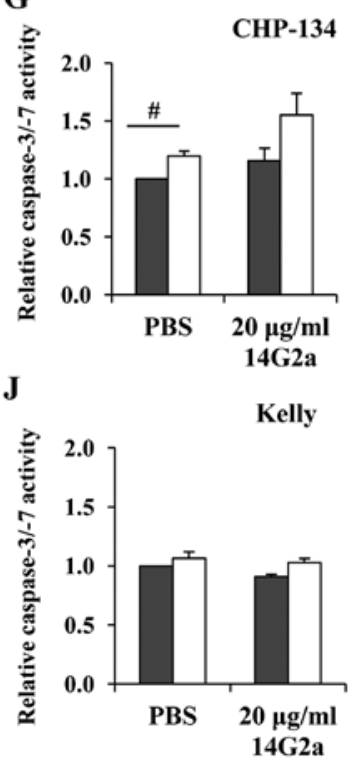

C

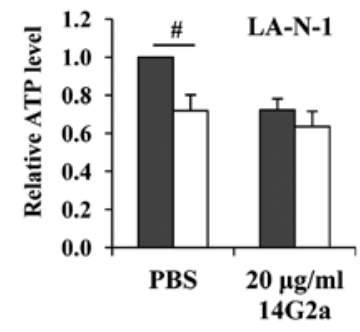

Adherent plate

Non-adherent plate

H

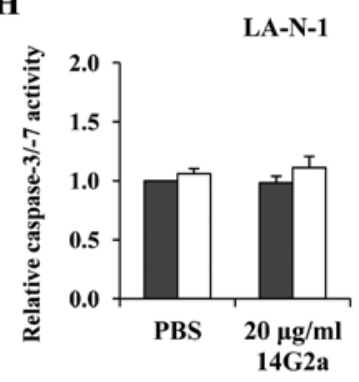

Adherent plate

Non-adherent plate

Figure 3. Effects of culture conditions on cell survival (measured with determination of cellular ATP levels) and activities of caspase-3/-7 of neuroblastoma cells. (A) IMR-32, (B) CHP-134, (C) LA-N-1, (D) LA-N-5 and (E) Kelly cells were cultured for 72 h on adherent plates (dark grey), or non-adherent plates (white) with the $14 \mathrm{G} 2 \mathrm{a} \mathrm{mAb}(20 \mu \mathrm{g} / \mathrm{ml})$. Control cells treated with PBS were also included. ATP levels were calculated relative to values of cells treated with PBS that were cultured on adherent plates (set as 1). Data were calculated as means of three (B and E) or four experiments (A, C and D), run in triplicate, with SEM on the error bars. (F) IMR-32, (G) CHP-134, (H) LA-N-1, (I) LA-N-5 and (J) Kelly cells were cultured for 72 h on adherent plates (dark grey), or non-adherent plates (white) with the $14 \mathrm{G} 2 \mathrm{a}$ mAb $(20 \mu \mathrm{g} / \mathrm{ml})$. Control cells treated with PBS were also included. Caspase-3/-7 activities were calculated relative to values of cells treated with PBS that were cultured on adherent plates (set as 1). Data were calculated as means of three experiments, run in duplicate, with SEM on the error bars. P-value for the t-test is as follows: \#p<0.05, \#\#p<0.01.

LA-N-1, LA-N-5, CHP-134 and Kelly neuroblastoma cell lines, as they are highly GD2-positive (Table I shows GD2 analyses on IMR-32, LA-N-5, CHP-134 and Kelly cells) and are to various extent sensitive to the antibody (10). We compared effects of attachment on survival of neuroblastoma cell lines, also in the presence of the mAb 14G2a (used in the concentration of $20 \mu \mathrm{g} / \mathrm{ml}$ ). First, we used ultra-low binding plates (non-adherent conditions) and standard cell culture plates (adherent conditions) to compare effects of such culture plastic vessels on cell morphology by microscopic observation and cell survival by measurements of cellular ATP. We report that all tested cell lines formed large aggregates on non-adherent plates (Fig. 2, right panel).
Also, we compared levels of cellular ATP in cultures after $72 \mathrm{~h}$ of incubation, with or without treatment with the mAb, on both types of plates (normalized to control cells treated with PBS and grown in adherent conditions, set as 1; Fig. 3A-E). We report a statistically significant decrease in cellular ATP of cell cultures grown on non-adherent plates as compared to standard culture plates. Thus, the measured values were from $0.62 \pm 0.03$ (for Kelly cells) to $0.75 \pm 0.045$ (for LA-N-5 cells) of the values of cells grown on the standard plates $(\mathrm{P}<0.05$ for CHP-134, LA-N-1, LA-N-5; P<0.01 for IMR-32 and Kelly). For the cells treated with $14 \mathrm{G} 2 \mathrm{a}$ (for the great majority of the tests), we measured lower ATP levels in cultures grown on nonadherent surfaces as compared to standard plates (Fig. 3A-E). 
A

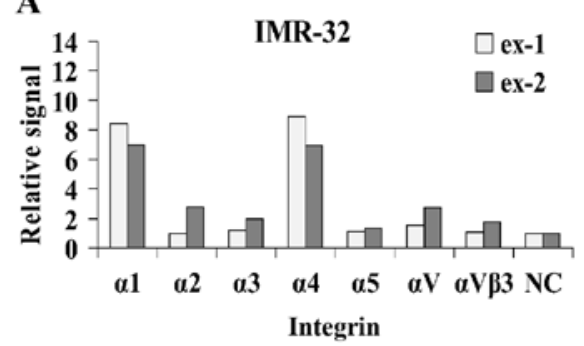

C

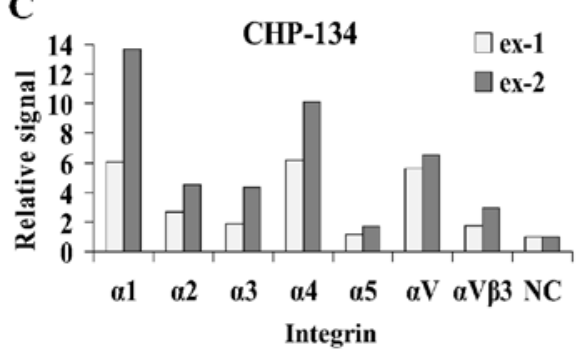

E

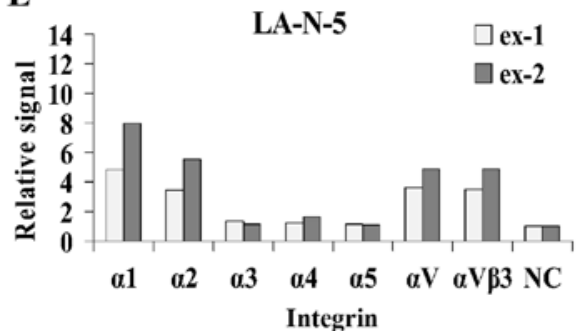

G

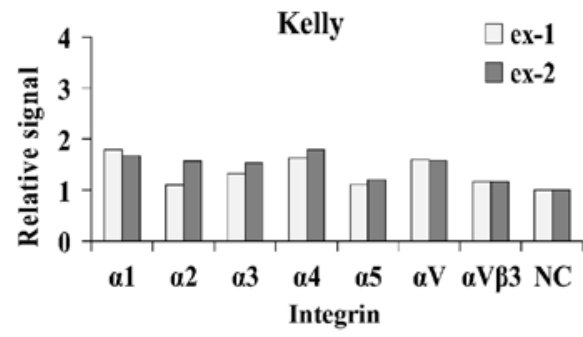

B

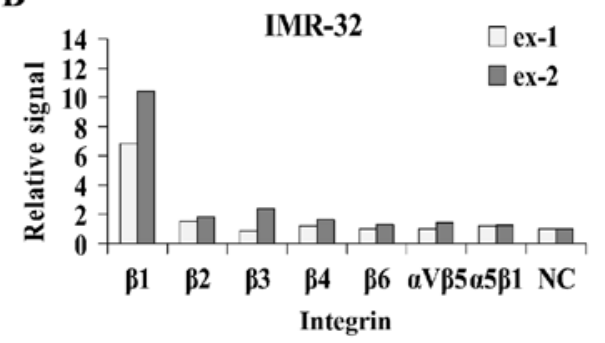

D

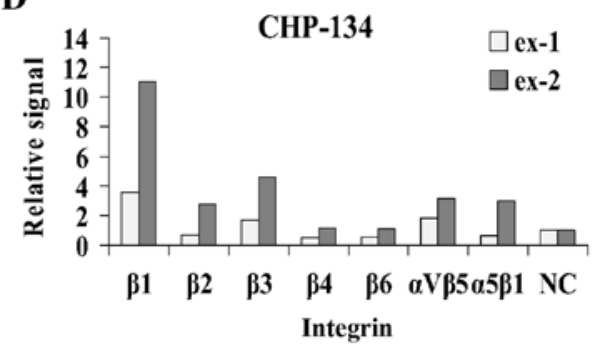

F

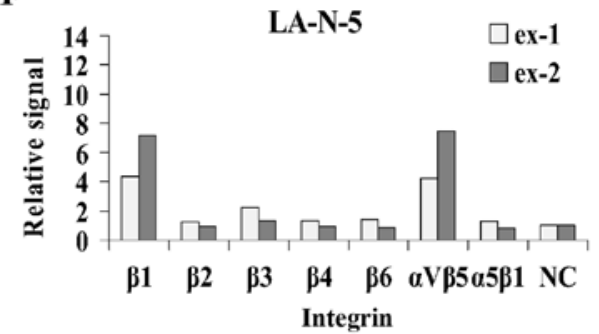

H

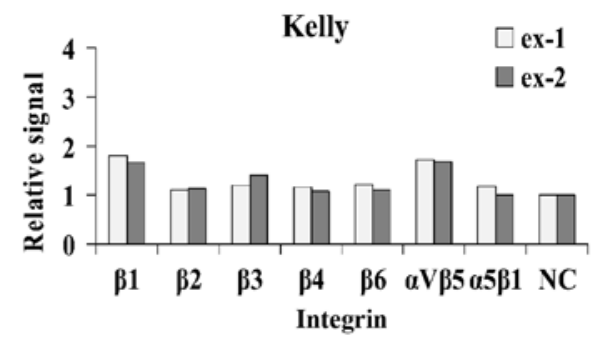

Figure 4. Expression of subunits or complexes of integrins on neuroblastoma cell lines. Data from two experiments (marked as ex-1 and ex-2 in the figures) are shown. Signal values are shown relative to respective negative control (marked as NC, set as 1). Signals were calculated as a ratio between a signal of cells retained in a well coated with a given anti-integrin antibody and a signal of cells retained in a control uncoated well. A relative signal $>2$ was taken as a positive sign that a given integrin subunit or complex is present on cells.

Out of five cell lines tested, for CHP-134 cells the ATP levels decreased approximately by additional $10 \%$ on non-adherent plates and were statistically meaningful for the $20 \mu \mathrm{g} / \mathrm{ml}$ concentrations of the $14 \mathrm{G} 2 \mathrm{a}$ mAb $(\mathrm{P}<0.05)$. For Kelly cells, the levels of ATP were statistically significantly lower for the $20 \mu \mathrm{g} / \mathrm{ml}$ concentration of the $14 \mathrm{G} 2 \mathrm{a}$ mAb used $(\mathrm{P}<0.01$; Fig. 3E). For IMR-32, LA-N-1 and LA-N-5 cells the results of $14 \mathrm{G} 2$ a treatment obtained compared between adherent and non-adherent conditions in the presence of the $14 \mathrm{G} 2 \mathrm{a}$ mAb were not statistically meaningful.

Previously, we reported that treatment with the mAb caused a rise in caspase-3/-7 activities in IMR-32 cells after 24 and $48 \mathrm{~h}$ of treatment (10). Here, we provide more data, showing that culturing of the IMR-32 cells for $72 \mathrm{~h}$ on non-adherent plates resulted in an increase of activities of caspase-3/-7 $\sim 20 \%$, but without statistical significance. However, for both adherent and non-adherent plates in the presence of $14 \mathrm{G} 2 \mathrm{a}$
(20 $\mu \mathrm{g} / \mathrm{ml})$, the increase of activities of caspase-3/-7 was $\sim 60$ and $70 \%$, respectively (Fig. 3F, when compared to control cells treated with PBS grown in adherent conditions, set as 1). Also, for CHP-134, LA-N-1 and LA-N-5 the highest activities of caspase-3/-7 were measured for cells cultured on low-binding plates and in the presence of the $14 \mathrm{G} 2 \mathrm{a} \mathrm{mAb}(20 \mu \mathrm{g} / \mathrm{ml})$, when compared to other conditions tested, but the data did not reach statistical significance due to variation between experiments (Fig. 3G-I).

Characterization of selected integrins on the cell surface of neuroblastoma cell lines. We made an attempt to preliminary characterize presence of integrins on IMR-32, CHP-134, LA-N-1, LA-N-5 and Kelly cell lines with application of an $\alpha / \beta$ integrin-mediated cell adhesion array that uses antibody-coated wells to retain cells expressing given integrin chains or their complexes (Fig. 4, data from two experiments 
A

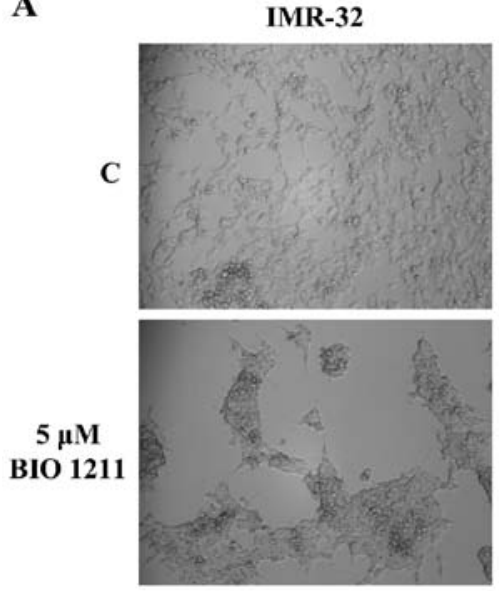

B
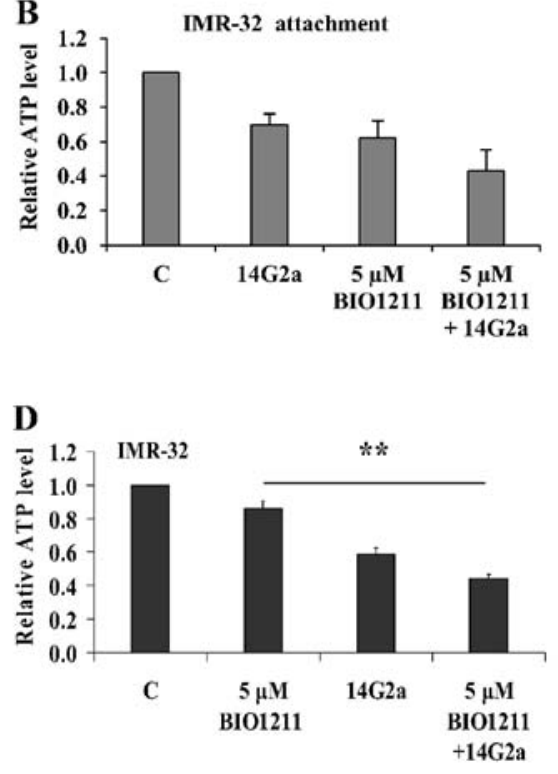

CHP-134
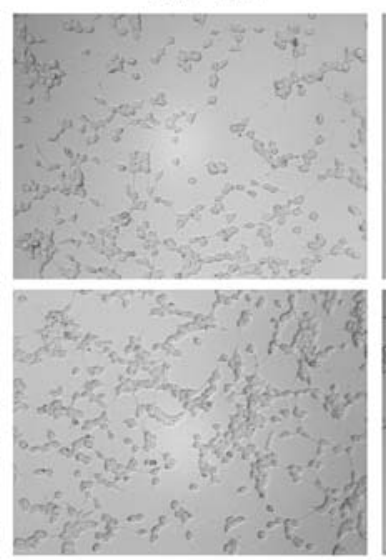

C

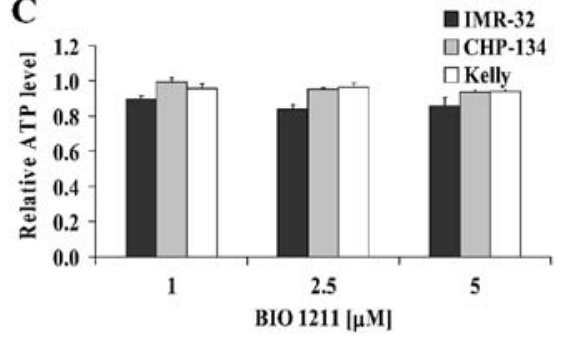

$\mathbf{E}$
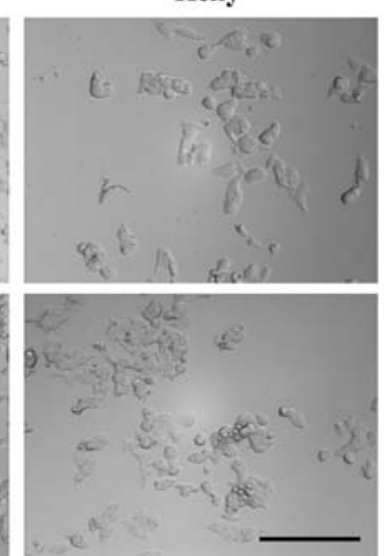

$\mathrm{B} 101211[\mu \mathrm{M} \mid$

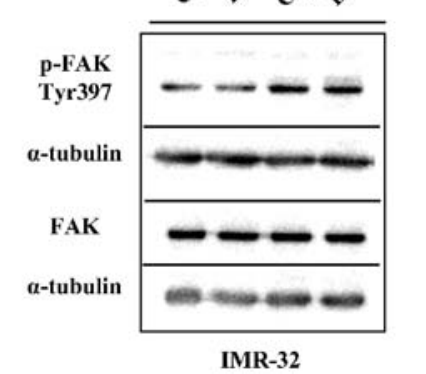

Figure 5. Effects of the specific inhibitor of active $\alpha 4 \beta 1$ integrin complex (BIO 1211) on appearance, attachment and cell survival of neuroblastoma cells cultured on fibronectin. (A) Representative microscopic pictures of IMR-32, CHP-134 and Kelly cells treated with diluents (marked as C) and $5 \mu$ M BIO 1211 . The magnification objective x20 was used, scale bar, $250 \mu \mathrm{m}$. (B) Attachment assay of IMR-32 cells on fibronectin-coated wells in the presence of 14G2a $(20 \mu \mathrm{g} / \mathrm{ml})$ and BIO $1211(5 \mu \mathrm{M})$. After $2 \mathrm{~h}$ of incubation unattached cells were removed, remaining cells were lysed, and levels of ATP were measured. (C) Survival of IMR-32, CHP-134 and Kelly cells treated with diluents and 1, 2.5 and $5 \mu \mathrm{M}$ BIO 1211, and cultured on fibronectin-coated plates (for $72 \mathrm{~h}$ ). (D) Survival of IMR-32 treated with diluent (marked as C) and $5 \mu \mathrm{M}$ BIO 1211, the 14G2a mAb $(20 \mu \mathrm{g} / \mathrm{ml})$, and the combination of the 14G2a mAb and BIO 1211 on fibronectin-coated plates (for $72 \mathrm{~h}$ ). Survival was measured through determination of ATP levels that were calculated relative to values of respective cells treated with diluents (set as 1). Multivariate analysis was performed with one-way repeated measures ANOVA with a Greenhouse-Geisser correction: [(B) F (1.149, 2.298)=12.475, P>0.058, (C) IMR-32, F(1.207, 2.415)=6.213, P>0.1; CHP-134, F(1.381, 2.761)=3.604, P>0.16; Kelly, F(1.995, 3.99)=4.09, P>0.10; (D) $\mathrm{F}(1.087,2.175)=16.046, \mathrm{P}<0.05]$. Pairwise comparisons by Dunnett's test at the significance levels ${ }^{* *} \mathrm{P}<0.01$, vs. $5 \mu \mathrm{M}$ BIO 1211. (D) Means $14 \mathrm{G} 2 \mathrm{a}$ vs. C, and $5 \mu \mathrm{M}$ BIO $1211+14 \mathrm{G} 2 \mathrm{a}$ vs. C were statistically different at the level 0.01 by Dunnett's test (omitted from the graph for clarity). Data on the graphs were calculated as means of three experiments, run in triplicate (C and D) or quadruplicate (B), with SEM on the error bars. (E) Western blot analysis of levels of p-FAK (Tyr397) and total FAK is IMR-32 cells treated with BIO $1211(5 \mu \mathrm{M})$ for 6 and $24 \mathrm{~h}$. Control cells (treated with diluent, marked as C, were also included). One of three experiments performed is shown. $\alpha$-tubulin was used as the reference protein.

are shown, marked as ex-1 and ex-2 on the graphs). For the analyses, we assumed that a relative signal $>2$ is a positive sign that a given integrin subunit or complex is present on cells. For IMR-32 and CHP-134 cells clear signals of binding of $\alpha 1, \alpha 4$ and $\beta 1$ chains were measured. Additionally, on CHP-134 cells $\alpha 2$ and $\alpha 3$ subunits were detected. On LA-N-5 cells $\alpha 1, \alpha 2$, and $\beta 1$ but no $\alpha 4$ were detected. Also, for CHP-134, LA-N-5 signals of binding to $\alpha \mathrm{V}, \alpha \mathrm{V} \beta 3$ and $\alpha \mathrm{V} \beta 5$ were measured. For Kelly cells due to high background measured in wells of controls it is hard to draw unequivocal conclusions, hence the line was included in the further tests (described below). Also for LA-N-1 cells, in one experiment, we measured positive signals from $\alpha 1, \alpha 2, \alpha 4, \alpha \mathrm{V}$ and $\beta 1$ (data not shown). Further testing was performed using flow cytometry (Table II shows percentage of positively stained cells in the analyzed pools). We showed that in concordance with the aforementioned array, $\beta 1$ integrin was expressed on majority of IMR-32, CHP-134, LA-N-5 and Kelly cells. Furthermore, $\alpha 4$ chain was unequivocally present in pools of analyzed IMR-32 cells (i.e., on $30 \%$ cells). On CHP-134 and Kelly cells, expression of $\alpha 4$ chain was detectable, yet restricted only to small percentage of cells (i.e., $3 \%$ of CHP-134 cells and $\sim 6.5 \%$ of Kelly cells). Lack of 


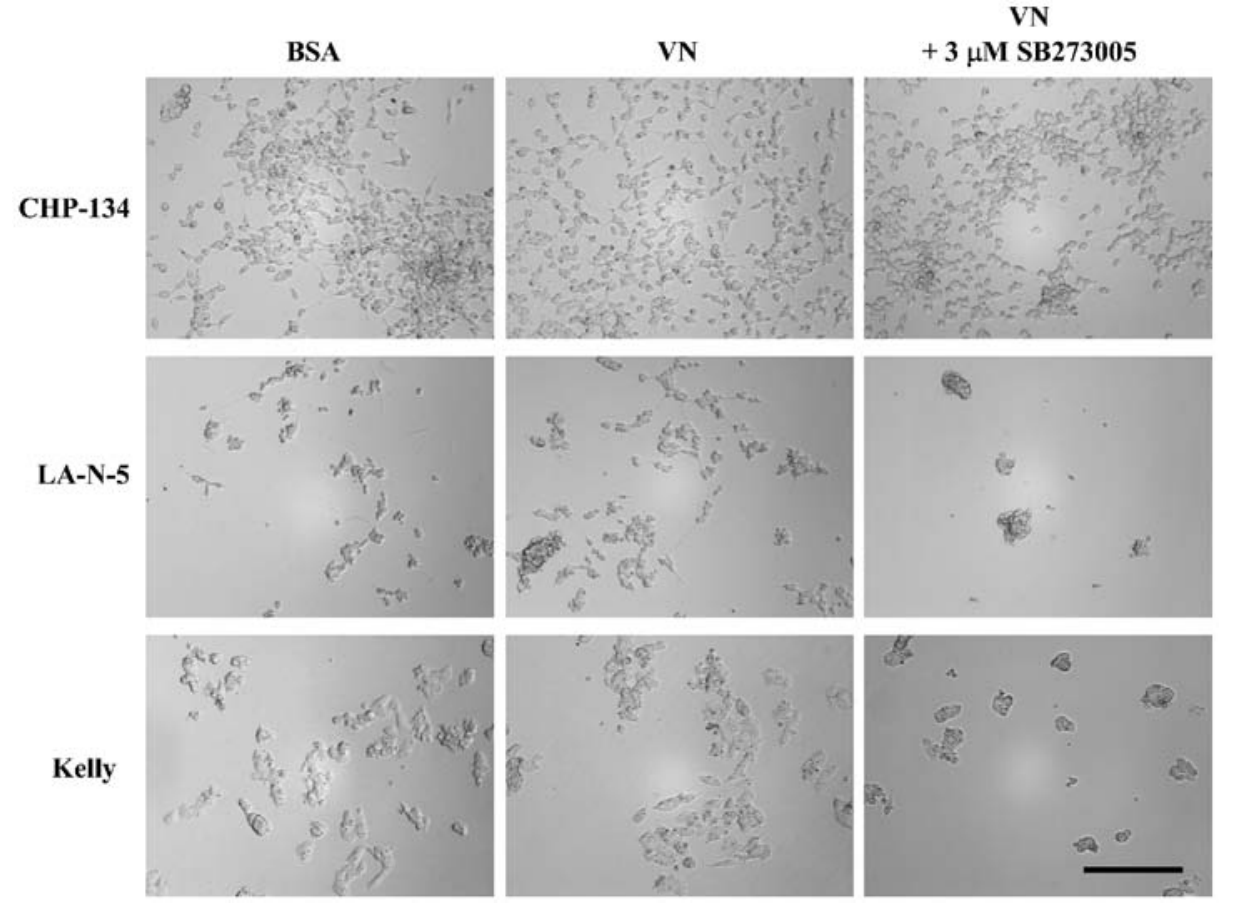

Figure 6. Effects of the specific inhibitor of $\alpha \mathrm{V} \beta 3$ and $\alpha \mathrm{V} \beta 5$ integrin complexes (SB273005) on appearance of neuroblastoma cells. Representative microscopic pictures of CHP-134, LA-N-5 and Kelly cells cultured for three days on BSA-blocked wells (BSA, left panel), vitronectin-coated and BSA-blocked wells (VN, middle panel), and vitronectin-coated and BSA-blocked wells in the presence of $3 \mu \mathrm{M} \mathrm{SB} 237005$ (VN $+3 \mu \mathrm{M} \mathrm{SB} 273005$, right panel). The magnification objective x20 was used, scale bar, $250 \mu \mathrm{m}$.

$\alpha \mathrm{V} \beta 3$ and $\alpha \mathrm{V} \beta 5$ heterodimers was confirmed on IMR-32 cells. The presence of the $\alpha \mathrm{V} \beta 3$ integrin complex was detectable on CHP-134, LA-N-5 and Kelly cell cultures, yet restricted only to minority of cells ( $2 \%)$. The $\alpha \mathrm{V} \beta 5$ complex was unequivocally present in Kelly cell pools ( $\sim 60 \%)$, while it was detectable only on minority of LA-N-5 and CHP-134 cells. Notably, in six measurements on LA-N-5 cells, percentage of cells positive for $\alpha \mathrm{V} \beta 3$ ranged approximately from 2 to $6 \%$, and for $\alpha \mathrm{V} \beta 5$ from 2.5 to $15 \%$ (data not shown). This suggests need for further characterization of levels of integrins and relationships between their expression and cell culture conditions (such as cell time in culture, culture cell density, or specific cell banks used). Additionally, we included GD2-negative SK-N-SH cells to the analyses (Table I) and showed that $\alpha 4, \beta 1$ chains and $\alpha \mathrm{V} \beta 3, \alpha \mathrm{V} \beta 3$ complexes are present in majority of the analyzed cells (Table II). Hence, the cell line was included in some research described in following chapters.

Characterization of sensitivity of neuroblastoma cell lines to treatment with the 14G2a mAb on surfaces coated with fibronectin and collagen $I V$. The above data prompted us to investigate effects of extracellular matrix proteins, i.e., fibronectin, collagen IV on changes of ATP levels induced after treatment of cells with the 14G2a mAb.

We compared cellular ATP levels of cells cultured on fibronectin- and collagen IV-coated wells to control cells grown on standard cell culture plates, after treatment with the $\mathrm{mAb}$ in the concentrations of $20 \mu \mathrm{g} / \mathrm{ml}$ (PBS treated cells were also included). The effects were subtle; hence we calculated data as means \pm SEM from three experiments (data not shown). For IMR-32, CHP-134 and LA-N-1 cells, we observed an increase in levels of cellular ATP on plates coated with fibronectin or collagen IV, when compared to cells grown on uncoated plates. However, the statistically meaningful increases in ATP levels $(\sim 10 \%)$ were measured only for the LA-N-1 cells treated with 14G2a and cultured on collagen IV plates $(\mathrm{P}<0.05)$. The smallest changes (and without statistical significance) were measured for CHP-134 cells. Thus, we find that interaction of neuroblastoma cells with the ECM proteins can lead to lower sensitivity of some cell lines to the mAb treatment.

Effects of inhibitors of $\alpha 1 \beta 1$ and $\alpha 4 \beta 1$ integrin complexes on appearance, attachment, survival of neuroblastoma cell lines and their sensitivity to $14 G 2 a \mathrm{mAb}$. We decided to use two inhibitors of integrin complexes $\alpha 1 \beta 1$ or $\alpha 4 \beta 1$, i.e., obtustatin or BIO 1211, to test their effects on IMR-32, CHP-134 and Kelly cells. The inhibitors were tested alone and in combination with the $14 \mathrm{G} 2 \mathrm{a} \mathrm{mAb}(20 \mu \mathrm{g} / \mathrm{ml})$ on plates coated with collagen IV or fibronectin, respectively.

Obtustatin used in the concentrations $0.012,0.06,0.3$ and $1.5 \mu \mathrm{M}$ did not affect ATP levels of IMR-32, CHP-134, Kelly cells (data not shown). Moreover, no change in sensitivity to treatment with 14G2a was observed when the inhibitor (applied in the above mentioned concentrations) was combined with $20 \mu \mathrm{g} / \mathrm{ml}$ of $14 \mathrm{G} 2 \mathrm{a}$ (after $72 \mathrm{~h}$ of treatment; data not shown). This is in line with the observations that the inhibitor did not induce changes of the cell morphology and attachment of the three lines, when investigated on the third day of culture by microscopic observation. Some cell rounding was observed $2 \mathrm{~h}$ after obtustatin (e.g., $1.5 \mu \mathrm{M}$ ) addition to IMR-32 cells (data not shown).

BIO 1211 used in the concentrations 1, 2.5 and $5 \mu \mathrm{M}$ affected appearance of IMR-32 cells, as visible after $72 \mathrm{~h}$ of culture, especially for 2.5 and $5 \mu \mathrm{M}$ BIO 1211 (Fig. 5A for 

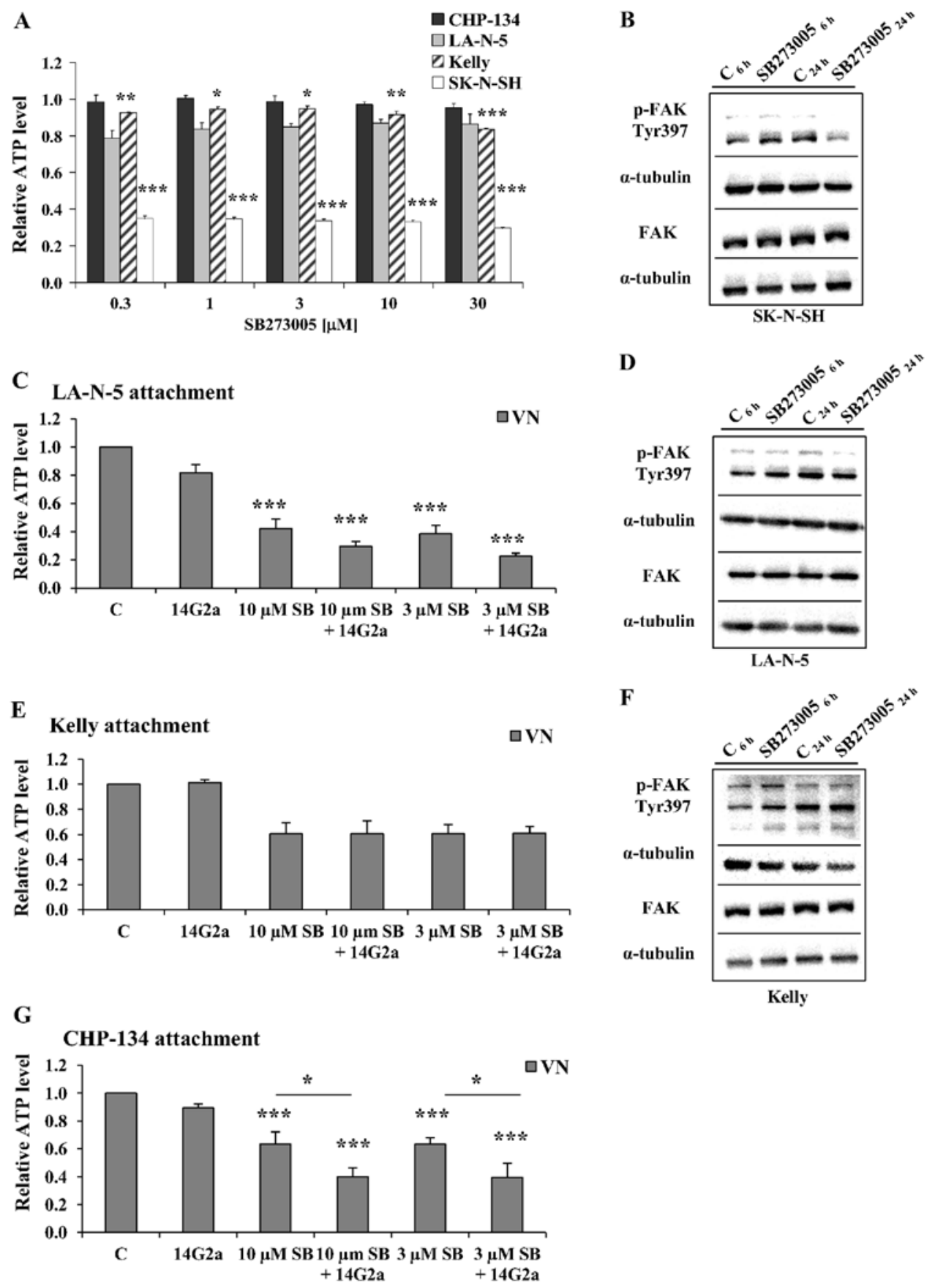

Figure 7. Effects of the specific inhibitor of $\alpha \mathrm{V} \beta 3$ and $\alpha \mathrm{V} \beta 5$ integrin complexes (SB273005) on attachment and survival of neuroblastoma cells. (A) Cellular ATP levels of neuroblastoma cells grown on uncoated plates. CHP-134, LAN-5, Kelly and SK-N-SH cells were treated with the inhibitor diluent (where appropriate, data not shown) or SB273005 (used in the concentrations ranging from 0.3 to $30 \mu \mathrm{M}$ ), and cultured on uncoated plates (for $72 \mathrm{~h}$ ). ATP levels were calculated relative to values of respective cells treated with diluent (set as 1). Attachment assay of (C) LA-N-5, (E) Kelly and (G) CHP-134 cells on fibronectin-coated wells. After $2 \mathrm{~h}$ of incubation unattached cells were removed, remaining cells were lysed, and levels of ATP were measured. Some cells were incubated in the presence of 14G2a $(20 \mu \mathrm{g} / \mathrm{ml})$ and/or SB273005 (3 and $10 \mu \mathrm{M})$. Multivariate analysis was performed with one-way repeated measures ANOVA with a Greenhouse-Geisser correction: [(A), CHP-134 - F(1.456, 2.912)=2.939, P>0.19, LA-N-5 - F(1.189, 2.378)=9.048, P>0.077; Kelly - F(1.707, 3.413) $=20.226$, P $<0.014$; SK-N-SH - F(1.057, 2.115) =152.193, P<0.005; (Fig. 5C) - F(1.424, 2.848)=27.359, P<0.015; (Fig. 5E) - F (1.015, 2.030)=9.371, P >0.09; (Fig. 5G) - F(1.379, 2.757) $=28.575, \mathrm{P}<0.016]$. Pairwise comparisons by Dunnett's test at the significance levels ${ }^{*} \mathrm{P}<0.05,{ }^{* *} \mathrm{P}<0.01,{ }^{{ }^{* * *} \mathrm{P}<0.001}$. Selected statistically significant comparisons are shown, while others were omitted (for clarity of $\mathrm{C}$ and $\mathrm{G}$ graphs). Data were calculated as means of three experiments, run in triplicate (A) or quadruplicate (C, E and G), with SEM on the error bars. (B, D and F) Western blot analysis of levels of p-FAK (Tyr397) and total FAK in SK-N-SH, LA-N-5 and Kelly cells treated with SB273005 $(3 \mu \mathrm{M})$ for $6 \mathrm{~h}$ (three experiments for LA-N-5, and two experiments for SK-N-SH and Kelly cells were performed) and $24 \mathrm{~h}$ (three experiments for SH-N-SH, LA-N-5 and Kelly cells were performed). One experiment is shown for each cell line. Control cells (treated with diluent, marked as $\mathrm{C}$, were also included). $\alpha$-tubulin was used as the reference protein.

$5 \mu \mathrm{M}$ BIO 1211), while no changes were observed for CHP-134 and Kelly cells. This was further analyzed with application of attachment assays on fibronectin-coated wells. The signals of cells remaining in wells were detected using ATP measurements. Results of multivariate analyses did not yield statistically significant P-values for the three cell lines, hence, 

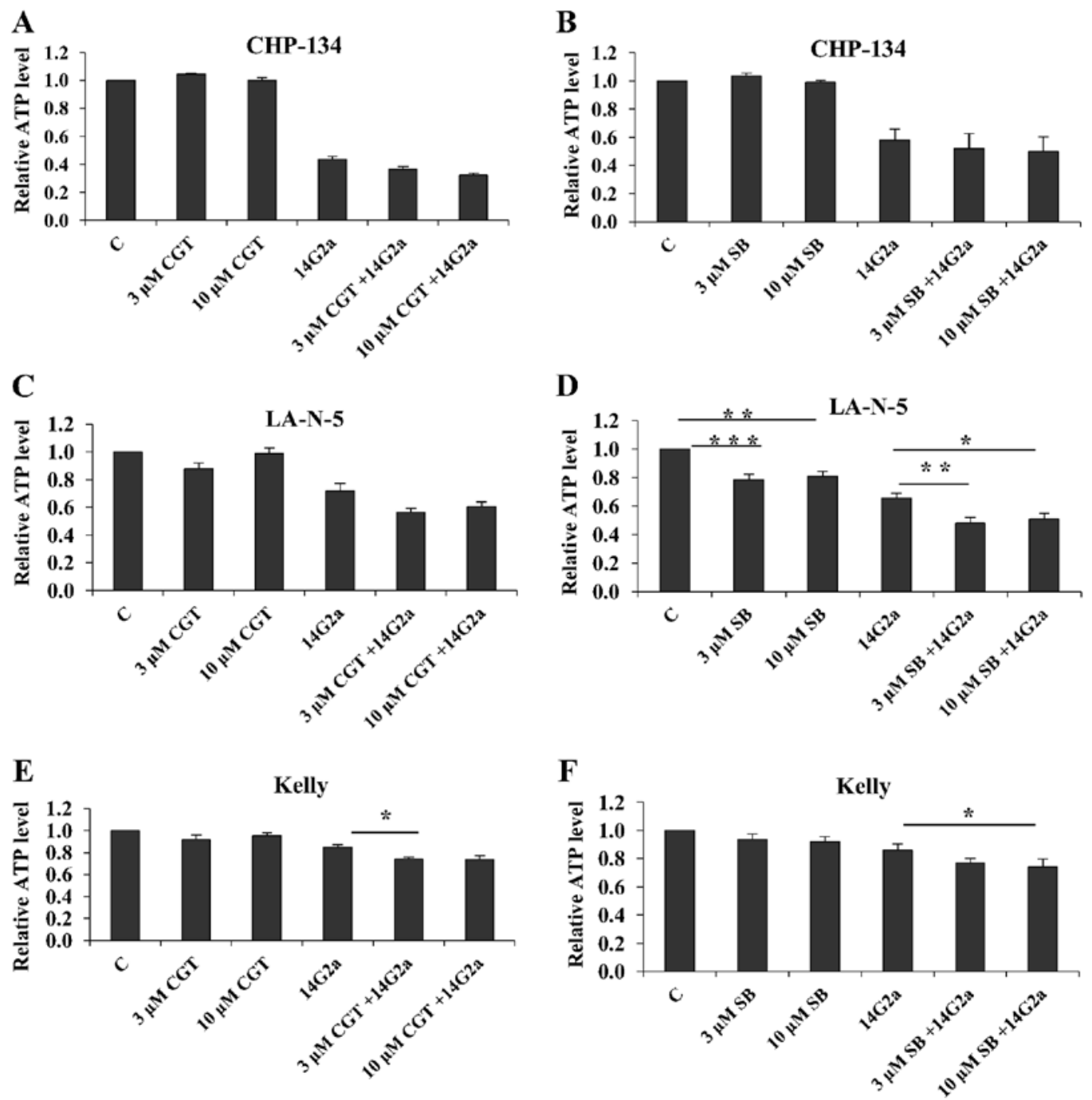

Figure 8. Effects of the specific inhibitors of $\alpha \mathrm{V} \beta 3$ and $\alpha \mathrm{V} \beta 5$ integrin complexes (cilengitide and SB273005) on cellular ATP levels of neuroblastoma cells. CHP-134, LAN-5 and Kelly cells treated with the inhibitor diluent (where appropriate, set as 1 in the figures), cilengitide (used in the concentrations of 3 and $10 \mu \mathrm{M}$, marked as CGT in A, C and E), SB273005 (used in the concentrations of 3 and $10 \mu \mathrm{M}$, marked as SB in B, D and F), combinations of the inhibitors and the 14G2a mAb $(20 \mu \mathrm{g} / \mathrm{ml})$ and cultured on vitronectin-coated and BSA-blocked wells (for $72 \mathrm{~h})$. ATP levels were calculated relative to values of cells treated with diluent (set as 1 in the figures). Multivariate analysis was performed with one-way repeated measures ANOVA with a Greenhouse-Geisser correction: $[(\mathrm{A})-\mathrm{F}(1,1)=13.813, \mathrm{P}>0.16 ;(\mathrm{B})-\mathrm{F}(1.042,4.169)=18.114, \mathrm{P}<0.012 ;(\mathrm{C})-\mathrm{F}(1.276,2.552)=14.608, \mathrm{P}<0.042 ;(\mathrm{D})-\mathrm{F}(1.368,4.104)=39.227, \mathrm{P}<0.0026$; (E) $-\mathrm{F}(1.604,3.207)=14.943, \mathrm{p}<0.025 ;(\mathrm{F})-\mathrm{F}(1.7,6.799)=10.987, \mathrm{P}<0.009]$. Pairwise comparisons by Dunnett's test at the significance levels ${ }^{*} \mathrm{P}<0.05,{ }^{* * *} \mathrm{P}<0.01$ and ${ }^{* * *} \mathrm{P}<0.001$ vs. C, and vs. 14G2a. Note that only significances between $\mathrm{C}$ vs. 10 and $3 \mu \mathrm{M}$ inhibitors, and 14G2a vs. combined treatments are shown, where present, while other were omitted (for clarity of graphs). Data were calculated as means of (A) two, (C and E) three, (D) four and (B and F) five experiments, run in triplicate, with SEM on the error bars.

further pairwise tests were not conducted (Fig. 5B and data not shown). For IMR-32, when mean values from three experiments were compared, the $14 \mathrm{G} 2 \mathrm{a} \mathrm{mAb}(20 \mu \mathrm{g} / \mathrm{ml})$ reduced signal to $0.7 \pm 0.06,5 \mu \mathrm{M}$ BIO 1211 reduced signal to $0.62 \pm 0.1$, and both agents reduced signal to $0.43 \pm 0.1$ of control cells set as 1 (Fig. 5B). For Kelly cells, the 14G2a mAb $(20 \mu \mathrm{g} / \mathrm{ml})$ did not affect attachment, $5 \mu \mathrm{M}$ BIO 1211 reduced signal to $0.93 \pm 0.4$, and both agents reduced signal to $0.89 \pm 0.04$, when compared to control cells (set as 1, data not shown). For CHP-134 cells, the $14 \mathrm{G} 2 \mathrm{a} \mathrm{mAb}(20 \mu \mathrm{g} / \mathrm{ml})$ and $5 \mu \mathrm{M}$ BIO 1211 did reduce signals, and both agents reduced signal to $0.86 \pm 0.05$, when compared to control cells (set as 1 , data not shown). Also after $72 \mathrm{~h}$ of culture, the inhibitor reduced cellular ATP levels of the IMR-32 cells to $0.9 \pm 0.02$ (of control cells treated with diluent, set as 1), $0.84 \pm 0.03$ (of control) and $0.86 \pm 0.04$ (of control); when used at the concentrations of $1,2.5$ and $5 \mu \mathrm{M}$, respectively (Fig. 5C).

When compared to IMR-32 cells treated with mAb alone, lower levels of ATP were observed for cells treated with combinations of $1,2.5$ and $5 \mu \mathrm{M}$ of BIO 1211 and $20 \mu \mathrm{g} / \mathrm{ml}$ of $14 \mathrm{G} 2 \mathrm{a}$ (after $72 \mathrm{~h}$ of treatment), i.e., $0.45 \pm 0.03$ (of control cells treated with diluent); $0.42 \pm 0.02$ (of control cells treated with diluent); $0.44 \pm 0.03$ (of control cells treated with diluent); respectively, yet the values did not reach statistical significance when compared to signals from samples treated only with 14G2a by Dunnett's test (Fig. 5D, also data not shown). For CHP-134 and Kelly cells treated with BIO 1211 in the concentrations $1,2.5$ and $5 \mu \mathrm{M}$ the reduction levels were either not observed (e.g., CHP-134 cells treated with $1 \mu \mathrm{M}$ ) or $<10 \%$ (Fig. 5C). No additional statistically meaningful effects were observed when the $14 \mathrm{G} 2 \mathrm{a}$ mAb 

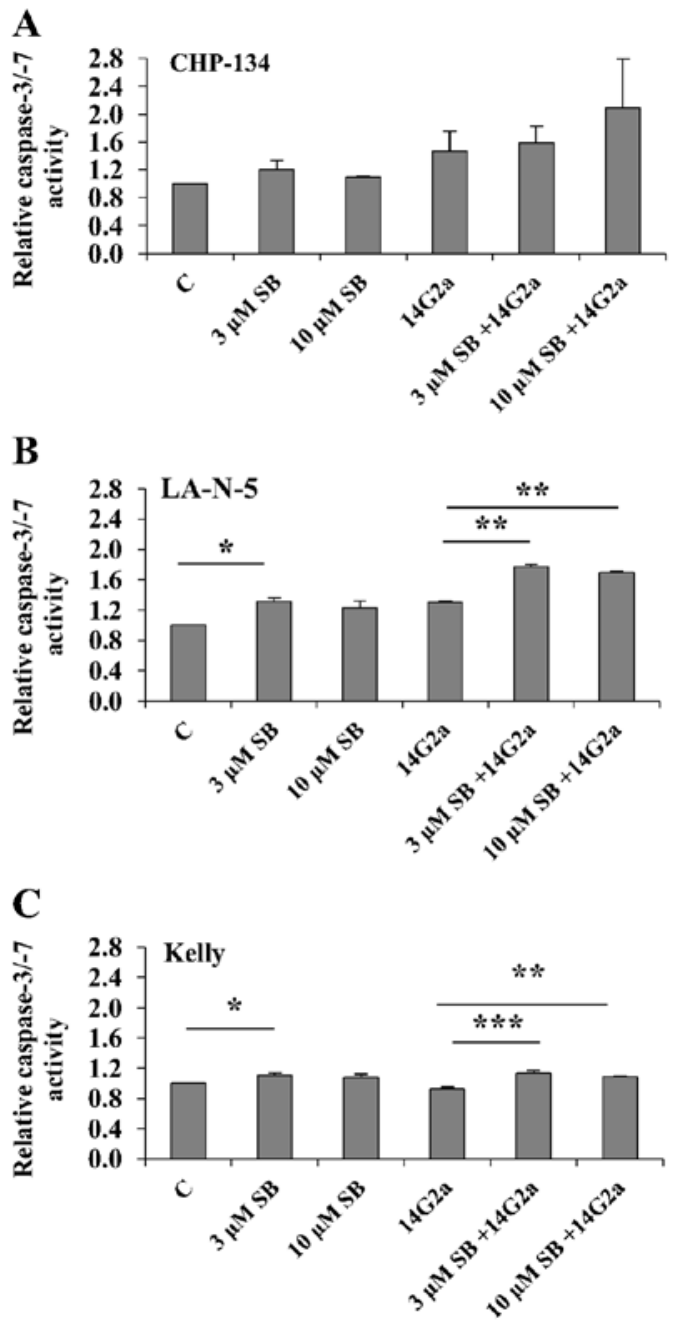

Figure 9. Effects of the specific inhibitor of $\alpha \mathrm{V} \beta 3$ and $\alpha \mathrm{V} \beta 5$ integrin complexes (SB273005) on caspase-3/-7 activities of neuroblastoma cells. CHP-134, LAN-5 and Kelly cells treated with the inhibitor diluent (where appropriate, set as 1 in the figures), SB273005 (used in the concentrations of 3 and $10 \mu \mathrm{M}$, marked as SB in A-C), combinations of the inhibitor and the 14G2a mAb $(20 \mu \mathrm{g} / \mathrm{ml})$, and cultured on vitronectin-coated and BSA-blocked wells (for $72 \mathrm{~h}$ ). Activities of caspase-3/-7 were calculated relative to values of cells treated with diluent. Multivariate analysis was performed with oneway repeated measures ANOVA with a Greenhouse-Geisser correction: [(A) - $\mathrm{F}(1.034,2.068)=3.825, \mathrm{P}>0.186,(\mathrm{~B})-\mathrm{F}(1.39,2.779)=20.318, \mathrm{P}<0.023$; (C) - $\mathrm{F}(1.744,3.487)=9.887, \mathrm{P}<0.038]$. Pairwise comparisons by Dunnett's test at the significance levels ${ }^{*} \mathrm{P}<0.05,{ }^{* * *} \mathrm{P}<0.01$ and ${ }^{* * * *} \mathrm{P}<0.001$. Selected statistically significant comparisons are shown, while others were omitted (for clarity of $\mathrm{B}$ and $\mathrm{C}$ graphs). Data were calculated as means of three experiments, run in duplicate, with SEM on the error bars.

(20 $\mu \mathrm{g} / \mathrm{ml}$ ) was combined with 2.5 and $5 \mu \mathrm{M}$ BIO 1211 for the CHP-134 cells [when compared to the antibody $(20 \mu \mathrm{g} / \mathrm{ml})$ used alone, data not shown]. For Kelly cells, in the settings where BIO $1211(1$ or 2.5 or $5 \mu \mathrm{M})$ and $14 \mathrm{G} 2 \mathrm{a}(20 \mu \mathrm{g} / \mathrm{ml})$ were used alone or the inhibitor and the $\mathrm{mAb}$ were used in combinations, multivariate analyses did not yield statistically significant P-values (data not shown). As a result, further pairwise tests were not conducted. Using western blot analysis, we showed that $5 \mu \mathrm{M}$ BIO 1211, added for 6 and $24 \mathrm{~h}$ to IMR-32 cells, did not change levels of p-FAK (Tyr397) and total FAK (Fig. 5E).

Effects of inhibitors of $\alpha V \beta 3$ and $\alpha V \beta 5$ integrin complexes on appearance, attachment, survival of neuroblastoma cell lines and their sensitivity to the $14 G 2 a m A b$. We decided to use two inhibitors of integrin complexes $\alpha \mathrm{V} \beta 3$ or $\alpha \mathrm{V} \beta 5$, i.e., cilengitide (CGT) or SB273005 (SB), to test their effects on LA-N-5, CHP-134 and Kelly cells. The inhibitors were tested alone and in combination with the $14 \mathrm{G} 2 \mathrm{a}$ mAb $(20 \mu \mathrm{g} / \mathrm{ml})$ on plates coated with vitronectin.

In cell cultures grown on vitronectin (VN), SB37005 (Fig. 6) and cilengitide (data not shown) induced changes: in shape (in Kelly cells), cell spreading (of CHP-134 cells), and aggregation (of LA-N-5 cells). Aggregation was evident for LA-N-5 cells, but for Kelly cells the cell rounding was quite subtle. CHP-134 cells tend to cover vitronectin-coated surface more evenly without SB273005 suggesting that their migration may be affected by it. Effects were observed for 3 and $10 \mu \mathrm{M}$ concentrations of both inhibitors (Fig. 6 and data not shown). Microscopic observations have been extended with attachment assays on vitronectin-coated wells. First, we report that vitronectin-coated wells retained more cells, $\sim 80 \%$ more for LA-N-5, 40\% more for Kelly, and approximately 30\% more for CHP-134, as compared to control, BSA blocked wells (after $2 \mathrm{~h}$ of incubation, $\mathrm{P}<0.01$ for LA-N-5, by two sample t-test, data not shown). Moreover, 3 and $10 \mu \mathrm{M}$ SB273005 used alone or in combination with $14 \mathrm{G} 2$ a statistically meaningfully reduced attachment of LA-N-5, CHP-134 (as compared to controls set as 1 , Fig. 7C and G) after $2 \mathrm{~h}$ of incubation. For Kelly cells, the inhibitor used alone or combined with $14 \mathrm{G} 2 \mathrm{a}$ reduced cell attachment by $\sim 40 \%$ (Fig. 7E). However, multivariate analysis did not yield statistically significant P-values (data not shown). As a result, further pairwise tests were not conducted.

Also, we tested SB273005 on uncoated plates in the range of concentrations from 0.3 to $30 \mu \mathrm{M}$. GD2-negative SK-N-SH cells known from the literature to express $\alpha \mathrm{V}$ (19) and from our cytometry data to express $\alpha \mathrm{V} \beta 3$ and $\alpha \mathrm{V} \beta 5$ were also included (Table II). When ATP levels were measured $72 \mathrm{~h}$ after addition of the inhibitor to cell cultures grown on standard uncoated wells, for SK-N-SH a clear cytotoxic effect was observed, as the cells were decimated for all conditions tested (Fig. 7A). The ATP levels of SH-N-SH dropped by $70 \%$ (Dunnett's test with the significance level set at 0.001 , as compared to control cells). In case of LA-N-5 cells, the ATP levels decreased $\sim 15 \%$ (but no significant P-value was obtained from multivariate analysis). For Kelly, ATP levels decreased $<10 \%$ (with statistical significance by Dunnett's test; Fig. 7A). No effects on cellular ATP levels were observed for CHP-134 incubated with SB273005 for $72 \mathrm{~h}$. Additionally, we analyzed levels of phosphorylated FAK, pFAK (Tyr397), and total FAK in SK-N-SH, LA-N-5 and Kelly treated with $3 \mu \mathrm{M}$ SB273005 for 6 and $24 \mathrm{~h}$ (Fig. 7B, D and F). No changes of levels of total FAK were observed. A clear drop in the level of phosphorylated FAK (Tyr397) was observed in SK-N-SH cell treated with the inhibitor for $24 \mathrm{~h}$ (Fig. 7B), which correlates with high toxicity of the inhibitor against the cell line.

Clear changes in cellular appearance, i.e., cell rounding, partial or complete aggregation and detachment, were observed for CHP-134, LA-N-1 and Kelly when cilengitide or SB273305 (10 and $3 \mu \mathrm{M})$ were combined with the $14 \mathrm{G} 2 \mathrm{a}$ $\mathrm{mAb}$ (for $72 \mathrm{~h}$, data not shown). Importantly the combination of cilengitide or SB273005 (10 and $3 \mu \mathrm{M})$ and $14 \mathrm{G} 2 \mathrm{a}$ (20 $\mu \mathrm{g} / \mathrm{ml})$ resulted in lower ATP levels, when compared to cells treated with the single drug, although the effects were 
rather small, possibly due to restricted expression of $\alpha \mathrm{V} \beta 3$ in cultures of CHP-134, LA-N-5, Kelly cells, and $\alpha \mathrm{V} \beta 5$ in cultures of CHP-134, LA-N-5 (Fig. 8 and Table II). For all cells effects of $14 \mathrm{G} 2 \mathrm{a}$ where statistically significant when compared to control cells (Dunnett's test, not marked on Fig. 8). For LA-N-5 the effects of the mAb were statistically significantly potentiated by 3 and $10 \mu \mathrm{M}$ SB273005 (Fig. 8D, Dunnett's test) and for Kelly for $3 \mu \mathrm{M}$ cilengitide and $10 \mu \mathrm{M}$ SB273005 (Fig. 8E and F, Dunnett's test). Also, SB273005 increased caspase-3/-7 activities in CHP-134, LA-N-5, Kelly cells (Fig. 9), and the effects were statistically meaningful for the last two cell lines mentioned (Fig. 9B and C; Dunnett's test). Importantly, for LA-N-5 and Kelly cells, the effects of the $\mathrm{mAb}$ were statistically significantly potentiated by 3 and $10 \mu \mathrm{M} \mathrm{SB} 273005$ (Fig. 9B and C, Dunnett's test).

\section{Discussion}

Numerous data support the view that cell signaling arising from interactions of tumor cells via integrins with the surrounding environment affects phenotype of the cells including their survival, degree of differentiation, potential to metastasize and resistance to drugs (reviewed in ref. 31). Over the past decades, reports on the expression of integrin in samples of neuroblastoma tumors from patients and established cell lines have accumulated (reviewed in ref. 32). Hence, it was shown that $\alpha 4$ and $\alpha 5$ integrins are expressed on stage III and IV neuroblastoma tumors, as well as on numerous neuroblastoma cell lines, where the receptors regulate cell motility (33). Additionally, Young et al (18) showed that integrin $\alpha 4$ may be associated with poor outcome in neuroblastoma patients without $M Y C N$ amplification. Hsu et al (34) reported that expression of the B4GALNT3 protein in tumor samples correlated with good outcome. More importantly, the authors showed that levels of the protein increased in SK-N-SH cells by all-trans retinoic acid-treatment. Also, they showed that B4GALNT3 expression suppressed cell migration and invasion along with downregulation of $\beta 1$ signaling (34). Furthermore, Leblond et al (35) showed expression of $\alpha \mathrm{V} \beta 3$ and $\alpha \mathrm{V} \beta 5$ on some neuroblastoma cell lines along with their sensitivity to cilengitide.

The results presented by us stemmed from our observation that in cell lines such as IMR-32, LA-N-1 and CHP-134, the treatment with the anti-GD2 14G2a mAb was accompanied by changes in cellular morphology (10) (Fig. 2). Additionally, we found that the nonadherent surface used for culture of all tested neuroblastoma cell lines led to decreased ATP levels. On the contrary, presence of fibronectin or collagen IV in wells where IMR-32 and LA-N-1 cells were treated with the $14 \mathrm{G} 2 \mathrm{a} \mathrm{mAb}$, led to increased values of cellular ATP. The above data encouraged us to investigate how selected inhibitors of integrins influenced cell sensitivity to 14G2a. Also, our report on the integrin expression on IMR-32, CHP-134, LA-N-1, LA-N-5, Kelly and SK-N-SH cells add to already published data and allowed us to plan experiments with the inhibitors used.

Based on the findings, we decided to take advantage of selective inhibitors of integrin complexes: obtustatin (inhibitor of $\alpha 1 \beta 1$ ), BIO 1211 (inhibitor of active $\alpha 4 \beta 1$ ), cilengitide and SB273005 (inhibitors of $\alpha \mathrm{V} \beta 3, \alpha \mathrm{V} \beta 5$ ) that were used alone or in combination with the $14 \mathrm{G} 2 \mathrm{a}$ mAb in our experiments. Our data showed that cellular ATP levels of IMR-32, CHP-134 and Kelly cells grown on collagen IV were not affected by obtustatin in the concentrations tested, with or without the $14 \mathrm{G} 2 \mathrm{a}$ mAb. Effects of BIO 1211 on cellular appearance and ATP levels were evident only for IMR-32 cells grown on fibronectin, possibly due to very restricted expression of $\alpha 4$ subunit in CHP-134 and Kelly cell cultures. No data on expression of $\alpha 4 \beta 1$ on the cell lines was obtained, due to the fact that no commercially available antibody specific for the human integrin complex was found. Due to limited expression of $\alpha 4$ and possibly of $\alpha 4 \beta 1$, multivariate analyses showed no significant differences of viability between cells treated with the $14 \mathrm{G} 2 \mathrm{a}$ mAb and combination of BIO 1211 and the mAb. Availability of antibodies recognizing $\alpha \mathrm{V} \beta 3, \alpha \mathrm{V} \beta 5$ complexes of integrins allows for correlation of observed effects of inhibitors with levels of expression of the hetrodimers on cells. Despite low percentages of cells expressing $\alpha \mathrm{V} \beta 3, \alpha \mathrm{V} \beta 5$ in cultures of LA-N-5 and CHP-134 cells, and $\alpha \mathrm{V} \beta 3$ in Kelly cell cultures, SB273005 and cilengitide caused aggregation and rounding in LA-N-5 and Kelly cultures, respectively, and seemed to affect cell spreading of CHP-134 cells, and SB273005 reduced attachment of the three cell lines. The changes were accompanied by decreased ATP levels after $72 \mathrm{~h}$ of incubation in LA-N-5 and Kelly cells. LA-N-5 cells were the most sensitive to combination of SB273005 and 14G2a. Notably, SB273005 was highly cytotoxic to the SK-N-SH cell line, even when the cells were grown on uncoated wells. The sensitivity of the cell line to the inhibitor may reflect the fact that $>85 \%$ of SK-N-SH cells express $\alpha \mathrm{V} \beta 3$ or $\alpha \mathrm{V} \beta 5$.

Future experiments should be planned on integrin-enriched pools of cells to characterize sensitivity of neuroblastoma cells positive for $\alpha 4 \beta 1, \alpha \mathrm{V} \beta 3$ and $\alpha \mathrm{V} \beta 5$ to inhibitors and the $14 \mathrm{G} 2 \mathrm{mAb}$, as $\alpha 4$ was shown to be linked to outcome in neuroblastoma (18) and the $\alpha \mathrm{V} \beta 3$ complex contributes to cancer stem cells, and along with $\alpha 4 \beta 1$ to bone metastasis (31). To gather more information, our future experiments should include testing other concentrations of the inhibitors. Also, testing for caspase-3/-7 activation in treated cell lines in additional time-points, such as 24 or $48 \mathrm{~h}$, to find if there is time-dependence in our models. Effects of our drugs on caspase- 8 activity can be tested (if expressed), as unligated or antagonized integrins promote caspase- 8 activation (36). Furthermore, the data could be extended with experiments investigating how the $14 \mathrm{G} 2 \mathrm{a}$ mAb (alone or in combination with the integrin antagonists) affect neuroblastoma migration and invasion. In that context, it would be interesting to characterize if expression and localization of integrins is affected by the $14 \mathrm{G} 2 \mathrm{a}$ in neuroblastoma. It is already established that treatment of some neuroblastoma cell lines with all-trans retinoic acid and fenretinide decreased levels of $\beta 1$ integrin (37). Combination of the inhibitors could also be used, as from the evidence of expression of several integrins in the cell lines and known overlap of their ligand specificities redundancy effects may be expected. It should be noted that a dual antagonist of $\alpha 1 \beta 1 / \alpha 2 \beta 1$ integrins was recently reported (38). Also, other proteins, i.e., galectins affecting integrin clustering, can be inhibited in our models (39). 
Wu et al (33) reported that migration of NB8 neuroblastoma cells mediated by $\alpha 5 \beta 1$ integrin involved pathways engaging SRC and FAK, but movement mediated by $\alpha 4 \beta 1$ integrin involved only SRC. We have already shown that dephosphorylation of $\beta$-catenin (phosphorylation of the protein is involved in anoikis resistance) (40), Tyr397 of FAK (the phosphorylation is important for cell survival) (41), an increase in activating phosphorylation of Tyr420 of FYN (expression of active FYN is linked to good outcome in neuroblastoma independently of $M Y C N$ amplification) (42), downregulation of AKT/mTOR network, a decrease in nuclear levels of MYCN (a known regulator of FAK expression) (43) are all linked among other changes of proteins to treatment of IMR-32 with $14 \mathrm{G} 2 \mathrm{a}(10,11)$. From the available literature, it is known that targeting kinases linked to integrin signaling can be exploited in neuroblastoma therapy. Therefore, a small molecule inhibitor of FAK affects neuroblastoma cell growth in vitro and in vivo, with greatest effects observed for cells with higher MYCN levels (41). Also, FAK/PAK1/MAPK cascade is linked to promotion of anchorage-independent growth by integrin $\beta 1$ in breast cancer cells (44). Thus, our data encourage for further characterization of signaling pathways involving integrins, also in neuroblastoma cells treated with integrin inhibitors, used alone or in combination with the 14G2a mAb. Again, in this context, neuroblastoma cell populations enriched for $\alpha 4$, $\alpha \mathrm{V} \beta 3$ and $\alpha \mathrm{V} \beta 5$ integrins should be used.

Finally, although our goals were focused on application of the inhibitors to verify involvement of their targets in sensitivity of selected cell lines to the 14G2a mAb, additional aspects of such drug combinations could be examined using in vivo models of neuroblastoma. This include testing of potential of tumor cells to metastasize to sites characteristic for high risk neuroblastoma such as bones or lymph nodes, in the presence of 14G2a and inhibitors of integrins, used alone and in combinations, possibly with neuroblastoma cell populations enriched for $\alpha 4, \alpha \mathrm{V} \beta 3$ and $\alpha \mathrm{V} \beta 5$ integrins. Such experiments could yield clinically relevant data. Effects on tumor growth, angiogenesis and immune system should be carefully evaluated, especially as the recent findings show that cilengitide failed to improve survival in glioblastoma in clinical trials (17). Also, Su et al (45) reported that targeting integrin $\beta 3$ with cilengitide increased immunosuppression in cancer models.

To summarize, we applied small molecule inhibitors of selected integrin complexes: obtustatin (inhibiting $\alpha 1 \beta 1$ ), BIO 1211 (inhibiting active $\alpha 4 \beta 1$ ), cilengitide and SB273005 (inhibitors of $\alpha \mathrm{V} \beta 3, \alpha \mathrm{V} \beta 5$ ) and verified their effects on appearance, attachment and survival of neuroblastoma cell lines, for the compounds used alone or in combination with the mAb. Our results broaden knowledge on factors influencing cytotoxicity against neuroblastoma cell lines evoked by 14G2a.

\section{Acknowledgements}

We are grateful to Dr R. Reisfeld for providing us with the hybridoma cell line producing the 14G2a mAb. We are grateful to Dr K. Stalińska, from the Department of Cellular Biochemistry; Faculty of Biochemistry, Biophysics and Biotechnology of the Jagiellonian University (Kraków, Poland) for her help with the collection of the microscopic images.
We are grateful to Dr Małgorzata Bzowska (Department of Immunology of the Faculty of Biochemistry, Biophysics and Biotechnology, Jagiellonian University) for her help with the flow cytometric analyses. We are grateful to SelleckChem. com for providing free aliquots of cilengitide and SB273005. This project was supported by grant no. NCN -2012/07/B/NZ 1/02808 from the Polish National Science Center (to H.R.) and DS/8/WBBiB UJ. We are grateful to the Departments of Medical Biotechnology and Cellular Biochemistry (Faculty of Biochemistry, Biophysics and Biotechnology of the Jagiellonian University, Kraków, Poland) for access to some equipment. Faculty of Biochemistry, Biophysics and Biotechnology is a partner of the Leading National Research Center (KNOW) supported by the Ministry of Science and Higher Education.

\section{References}

1. Cheung NK and Dyer MA: Neuroblastoma: Developmental biology, cancer genomics and immunotherapy. Nat Rev Cancer 13: 397-411, 2013.

2. Schmidt ML, Lal A, Seeger RC, Maris JM, Shimada H, O'Leary M, Gerbing RB and Matthay KK: Favorable prognosis for patients 12 to 18 months of age with stage 4 nonamplified MYCN neuroblastoma: A Children's Cancer Group Study. J Clin Oncol 23: 6474-6480, 2005.

3. Pugh TJ, Morozova O, Attiyeh EF, Asgharzadeh S, Wei JS, Auclair D, Carter SL, Cibulskis K, Hanna M, Kiezun A, et al: The genetic landscape of high-risk neuroblastoma. Nat Genet 45: 279-284, 2013.

4. Smith MA, Seibel NL, Altekruse SF, Ries LA, Melbert DL, O'Leary M, Smith FO and Reaman GH: Outcomes for children and adolescents with cancer: Challenges for the twenty-first century. J Clin Oncol 28: 2625-2634, 2010.

5. Navid F, Santana VM and Barfield RC: Anti-GD2 antibody therapy for GD2-expressing tumors. Curr Cancer Drug Targets 10: 200-209, 2010.

6. Hoy SM: Dinutuximab: A review in high-risk neuroblastoma. Target Oncol 11: 247-253, 2016.

7. Yu AL, Gilman AL, Ozkaynak MF, London WB, Kreissman SG, Chen HX, Smith M, Anderson B, Villablanca JG, Matthay KK, et al; Children's Oncology Group: Anti-GD2 antibody with GM-CSF, interleukin-2, and isotretinoin for neuroblastoma. N Engl J Med 363: 1324-1334, 2010.

8. Horwacik I and Rokita H: Targeting of tumor-associated gangliosides with antibodies affects signaling pathways and leads to cell death including apoptosis. Apoptosis 20: 679-688, 2015.

9. Cochonneau D, Terme M, Michaud A, Dorvillius M, Gautier N, Frikeche J, Alvarez-Rueda N, Bougras G, Aubry J, Paris F, et al: Cell cycle arrest and apoptosis induced by $O$-acetyl-GD2-specific monoclonal antibody 8B6 inhibits tumor growth in vitro and in vivo. Cancer Lett 333: 194-204, 2013.

10. Horwacik I, Durbas M, Boratyn E, Węgrzyn P and Rokita H: Targeting GD2 ganglioside and aurora A kinase as a dual strategy leading to cell death in cultures of human neuroblastoma cells. Cancer Lett 341: 248-264, 2013.

11. Durbas M, Horwacik I, Boratyn E, Kamycka E and Rokita H: GD2 ganglioside specific antibody treatment downregulates $\mathrm{PI} 3 \mathrm{~K} / \mathrm{Akt} / \mathrm{mTOR}$ signaling network in human neuroblastoma cell lines. Int J Oncol 47: 1143-1159, 2015.

12. Hynes RO: Integrins: Bidirectional, allosteric signaling machines. Cell 110: 673-687, 2002.

13. Bouvard D, Pouwels J, De Franceschi N and Ivaska J: Integrin inactivators: Balancing cellular functions in vitro and in vivo. Nat Rev Mol Cell Biol 14: 430-442, 2013.

14. Jin $\mathrm{H}$ and Varner J: Integrins: Roles in cancer development and as treatment targets. Br J Cancer 90: 561-565, 2004.

15. Hersey P, Sosman J, O'Day S, Richards J, Bedikian A, Gonzalez R, Sharfman W, Weber R, Logan T, Buzoianu M, et al; Etaracizumab Melanoma Study Group: A randomized phase 2 study of etaracizumab, a monoclonal antibody against integrin $\alpha_{v} \beta_{3}, \pm$ dacarbazine in patients with stage IV metastatic melanoma. Cancer 116: 1526-1534, 2010. 
16. Bell-McGuinn KM, Matthews CM, Ho SN, Barve M, Gilbert L, Penson RT, Lengyel E, Palaparthy R, Gilder K, Vassos A, et al: A phase II, single-arm study of the anti- $\alpha 5 \beta 1$ integrin antibody volociximab as monotherapy in patients with platinum-resistant advanced epithelial ovarian or primary peritoneal cancer. Gynecol Oncol 121: 273-279, 2011.

17. Stupp R, Hegi ME, Gorlia T, Erridge SC, Perry J, Hong YK, Aldape KD, Lhermitte B, Pietsch T, Grujicic D, et al; European Organisation for Research and Treatment of Cancer (EORTC); Canadian Brain Tumor Consortium; CENTRIC study team: Cilengitide combined with standard treatment for patients with newly diagnosed glioblastoma with methylated MGMT promoter (CENTRIC EORTC 26071-22072 study): A multicentre, randomised, open-label, phase 3 trial. Lancet Oncol 15 : 1100-1108, 2014.

18. Young SA, McCabe KE, Bartakova A, Delaney J, Pizzo DP, Newbury RO, Varner JA, Schlaepfer DD and Stupack DG: Integrin $\alpha 4$ enhances metastasis and may be associated with poor prognosis in MYCN-low neuroblastoma. PLoS One 10 : e0120815, 2015.

19. Lee S, Qiao J, Paul P and Chung DH: Integrin $\beta 1$ is critical for gastrin-releasing peptide receptor-mediated neuroblastoma cell migration and invasion. Surgery 154: 369-375, 2013.

20. Cheresh DA, Pierschbacher MD, Herzig MA and Mujoo K: Disialogangliosides GD2 and GD3 are involved in the attachment of human melanoma and neuroblastoma cells to extracellular matrix proteins. J Cell Biol 102: 688-696, 1986.

21. Ohkawa Y, Miyazaki S, Miyata M, Hamamura K, Furukawa K and Furukawa K: Essential roles of integrin-mediated signaling for the enhancement of malignant properties of melanomas based on the expression of GD3. Biochem Biophys Res Commun 373: 14-19, 2008.

22. Dippold WG, Knuth A and Meyer zum Büschenfelde KH: Inhibition of human melanoma cell growth in vitro by monoclonal anti-GD3-ganglioside antibody. Cancer Res 44: 806-810, 1984.

23. Kowalczyk A, Gil M, Horwacik I, Odrowaz Z, Kozbor D and Rokita H: The GD2-specific 14G2a monoclonal antibody induces apoptosis and enhances cytotoxicity of chemotherapeutic drugs in IMR-32 human neuroblastoma cells. Cancer Lett 281: 171-182, 2009.

24. Marcinkiewicz C, Weinreb PH, Calvete JJ, Kisiel DG, Mousa SA, Tuszynski GP and Lobb RR: Obtustatin: A potent selective inhibitor of alphalbetal integrin in vitro and angiogenesis in vivo. Cancer Res 63: 2020-2023, 2003.

25. Lin K, Ateeq HS, Hsiung SH, Chong LT, Zimmerman $\mathrm{CN}$, Castro A, Lee WC, Hammond CE, Kalkunte S, Chen LL, et al: Selective, tight-binding inhibitors of integrin alpha4beta1 that inhibit allergic airway responses. J Med Chem 42: 920-934, 1999.

26. Taga T, Suzuki A, Gonzalez-Gomez I, Gilles FH, Stins M, Shimada H, Barsky L, Weinberg KI and Laug WE: alpha v-integrin antagonist EMD 121974 induces apoptosis in brain tumor cells growing on vitronectin and tenascin. Int J Cancer 98: 690-697, 2002.

27. Gomes N, Vassy J, Lebos C, Arbeille B, Legrand C and Fauvel-Lafeve F: Breast adenocarcinoma cell adhesion to the vascular subendothelium in whole blood and under flow conditions: Effects of alphavbeta3 and alphaIIbbeta3 antagonists. Clin Exp Metastasis 21: 553-561, 2004.

28. Horwacik I, Kurciński M, Bzowska M, Kowalczyk AK, Czaplicki D, Koliński A and Rokita H: Analysis and optimization of interactions between peptides mimicking the GD2 ganglioside and the monoclonal antibody 14G2a. Int J Mol Med 28: 47-57, 2011.

29. Horwacik I, Golik P, Grudnik P, Kolinski M,Zdzalik M, Rokita H and Dubin G: Structural basis of GD2 ganglioside and mimetic peptide recognition by 14G2a antibody. Mol Cell Proteomics 14: 2577-2590, 2015.
30. Lew M: Good statistical practice in pharmacology. Problem 2. Br J Pharmacol 152: 299-303, 2007.

31. Seguin L, Desgrosellier JS, Weis SM and Cheresh DA: Integrins and cancer: Regulators of cancer stemness, metastasis, and drug resistance. Trends Cell Biol 25: 234-240, 2015.

32. Young SA, Graf R and Stupack DG: Neuroblastoma integrins. In: Neuroblastoma. Hiroyuki S (ed). InTech Press, Rijeka, Croatia, pp189-216, 2013.

33. Wu L, Bernard-Trifilo JA, Lim Y, Lim ST, Mitra SK, Uryu S, Chen M, Pallen CJ, Cheung NK, Mikolon D, et al: Distinct FAK-Src activation events promote alpha5beta1 and alpha4beta1 integrin-stimulated neuroblastoma cell motility. Oncogene 27: $1439-1448,2008$

34. Hsu WM, Che MI, Liao YF, Chang HH, Chen CH, Huang YM, Jeng YM, Huang J, Quon MJ, Lee H, et al: B4GALNT3 expression predicts a favorable prognosis and suppresses cell migration and invasion via $\beta_{1}$ integrin signaling in neuroblastoma. Am J Pathol 179: 1394-1404, 2011.

35. Leblond P, Dewitte A, Le Tinier F, Bal-Mahieu C, Baroncini M, Sarrazin T, Lartigau E, Lansiaux A and Meignan S: Cilengitide targets pediatric glioma and neuroblastoma cells through cell detachment and anoikis induction. Anticancer Drugs 24: 818-825, 2013.

36. Stupack DG, Puente XS, Boutsaboualoy S, Storgard CM and Cheresh DA: Apoptosis of adherent cells by recruitment of caspase-8 to unligated integrins. J Cell Biol 155: 459-470, 2001.

37. Rozzo C, Chiesa V, Caridi G, Pagnan G and Ponzoni M: Induction of apoptosis in human neuroblastoma cells by abrogation of integrin-mediated cell adhesion. Int J Cancer 70: 688-698, 1997.

38. Momic T, Katzehendler J, Benny O, Lahiani A, Cohen G, Noy E, Senderowitz H, Eble JA, Marcinkiewicz C and Lazarovici P: Vimocin and vidapin, cyclic KTS peptides, are dual antagonists of $\alpha 1 \beta 1 / \alpha 2 \beta 1$ integrins with antiangiogenic activity. J Pharmacol Exp Ther 350: 506-519, 2014.

39. Cagnoni AJ, Pérez Sáez JM, Rabinovich GA and Mariño KV: Turning-off signaling by siglecs, selectins, and galectins: Chemical inhibition of glycan-dependent interactions in cancer. Front Oncol 6: 109, 2016.

40. Yoo BH, Masson O, Li Y, Khan IA, Gowda PS and Rosen KV: Anoikis of colon carcinoma cells triggered by $\beta$-catenin loss can be enhanced by tumor necrosis factor receptor 1 antagonists. Oncogene 34: 4939-4951, 2015.

41. Beierle EA, Ma X, Stewart J, Nyberg C, Trujillo A, Cance WG and Golubovskaya VM: Inhibition of focal adhesion kinase decreases tumor growth in human neuroblastoma. Cell Cycle 9: 1005-1015, 2010

42. Berwanger B, Hartmann O, Bergmann E, Bernard S, Nielsen D, Krause M, Kartal A, Flynn D, Wiedemeyer R, Schwab M, et al: Loss of a FYN-regulated differentiation and growth arrest pathway in advanced stage neuroblastoma. Cancer Cell 2: 377-386, 2002.

43. Beierle EA, Trujillo A, Nagaram A, Kurenova EV, Finch R, Ma X, Vella J, Cance WG and Golubovskaya VM: N-MYC regulates focal adhesion kinase expression in human neuroblastoma. J Biol Chem 282: 12503-12516, 2007.

44. Cagnet S, Faraldo MM, Kreft M, Sonnenberg A, Raymond K and Glukhova MA: Signaling events mediated by $\alpha 3 \beta 1$ integrin are essential for mammary tumorigenesis. Oncogene 33: 4286-4295, 2014.

45. Su X, Esser AK, Amend SR, Xiang J, Xu Y, Ross MH, Fox GC, Kobayashi T, Steri V, Roomp K, et al: Antagonizing integrin $\beta 3$ increases immunosuppression in cancer. Cancer Res 76 : 3484-3495, 2016 